\title{
Structural, Morphological, Optical, Luminescent and Magnetic Properties of Nanostructured ZnO Thin Film
}

Visweswaran S ( $\nabla$ visudharan@gmail.com )

Annamalai University https://orcid.org/0000-0002-9631-7496

R. Venkatachalapathy

Annamalai University

M. Haris

Karunya Institute of Technology and Sciences

R. Murugesan

Thiru Kolanjiappar Government Arts College

Research Article

Keywords: ZnO thin film, substrate temperature, highly transparent, weak ferromagnetic behavior

Posted Date: March 1st, 2021

DOI: https://doi.org/10.21203/rs.3.rs-243700/v1

License: (a) (i) This work is licensed under a Creative Commons Attribution 4.0 International License.

Read Full License 


\title{
Structural, Morphological, Optical, Luminescent and Magnetic properties of nanostructured ZnO Thin Film
}

\author{
S.Visweswaran ${ }^{1,}$, , R.Venkatachalapathy ${ }^{1}$, M.Haris ${ }^{2}$, R.Murugesan ${ }^{3}$ \\ ${ }^{1}$ Department of Physics, Annamalai University, Chidambaram, Tamilnadu - 608002 \\ ${ }^{2}$ Department of Physics, Karunya Institute of Technology and Sciences, Coimbatore - \\ 641114Tamilnadu \\ ${ }^{3}$ PG and Research Department of Physics, Thiru Kolanjiappar Government Arts College, \\ Vridhachallam - 606001, Tamilnadu
}

\section{Corresponding author email id: visudharan@gmail.com}

\begin{abstract}
$\mathrm{ZnO}$ thin film deposited on the glass substrate at various substrate temperature by spray technique using perfume atomizer. The deposited $\mathrm{ZnO}$ thin films are annealed at $450^{\circ} \mathrm{C}$. The deposited films are highly transparent and adhered to the substrate. The structure and microstructural, morphological, compositional, optical and luminescent characteristics were studied by X-ray diffraction (XRD), Raman, Field emission scanning electron microscope (FESEM with EDX), Atomic force microscope (AFM), Ultra violet visible spectrophotometer (UVVis) and photoluminescence spectroscopic techniques. The crystalline nature of annealed film were confirmed from XRD and the shows preferred orientation along (lll 101$)$ plane. At higher substrate temperature, reorientation of planes was seen. The spherical shaped grains are observed from morphological studies. The roughness of $\mathrm{ZnO}$ film, one of the key parameter obtained from AFM, increases with substrate temperature. The high transparency of about $80 \%$ in visible region are obtained for $\mathrm{ZnO}$ film with band gap ranging from $3.24-3.19 \mathrm{eV}$. The presence of defects in $\mathrm{ZnO}$ films are identified from PL bands. The electronic vibrations in $\mathrm{ZnO}$ film were understood from Raman spectra. The weak ferromagnetic behavior at room temperature is
\end{abstract}


observed and exchange interactions stemming from oxygen vacancy produce BMP and subject to RTFM in $\mathrm{ZnO}$.

Keywords: $\mathrm{ZnO}$ thin film, substrate temperature, highly transparent, weak ferromagnetic behavior.

\subsection{Introduction}

$\mathrm{ZnO}$ belonging to II - VI element, is a compound semiconductor. Its energy band gap is $3.37 \mathrm{eV}$ and it possesses large exciton binding energy. The $\mathrm{ZnO}$ crystallizes in three forms a. zinc blende, b. rock salt, and c. wurtzite. The stable $\mathrm{ZnO}$ phase (hexagonal wurtzite) is obtained thermodynamically at room temperature, where each $\mathrm{Zn}^{2+}$ ions are surrounded by four $\mathrm{O}^{2-}$ at the corners of the tetragon. The $\mathrm{ZnO}$ based $\mathrm{TCO}$ film is known for its exceptional performance, so it is used in variety of industrial and medicare applications such as piezoelectric and pyroelectric properties [1], surface acoustive wave devices (SAW), biosensors, drug delivery, anti microbial and antifungal activity, spintronics and optoelectronic devices [2], solar cells [3], photodetector and photovoltaics, photoelectrochemical water splitting [4], photocatalytic [5], gas sensor [6]. The $\mathrm{ZnO}$ films were grown from inorganic and organic precursors such as nitrates, chlorides, perchlorates, acetates and acetylacetonates respectively were reported by number of authors [7]. The ripple like morphology is obtained for spin coated $\mathrm{ZnO}$ film, cubic like structures is noticed for the spin coated $\mathrm{ZnO}$ by solution growth at various time interval and flakes like formation is seen for $\mathrm{ZnO}$ film doped with $\mathrm{Al}$ is reported [8]. T. Srinivasulu et.al, investigated the influence of Fe doped $\mathrm{ZnO}$ film by spray pyrolysis. No structural deformation is observed for the Fe doped $\mathrm{ZnO}$ film. Also, $\mathrm{ZnO}$ film shows the paramagnetic behavior in pure form and ferromagnetic for Fe doped film [9]. The microstructures of $\mathrm{ZnO}$ thin film such as spindle like, rod, hexagonal 
plate like morphologies at different molar concentration are investigated [10]. The $\mathrm{ZnO}$ film obtained with $c / / n$ and $a / / n$ orientation reported by L.Znaidi.et.al [11]. Ahamed et al. investigated the optical and structural properties of $\mathrm{B}$ doped $\mathrm{ZnO}$ nanostructures by sol gel technique. The preferred orientation of (002) plane vanished for $\mathrm{B}$ doped $\mathrm{ZnO}$. The grain size increased with the dopant concentration and the irregularity in film's morphology. The $\mathrm{ZnO}$ film achieved 90\% transmittance in visible region decreases with dopant concentration. The Eg of $\mathrm{ZnO}$ film decreases as the grain size increases [12]. Alsaad et al, fabricated transparent $\mathrm{ZnO}$ thin film whose transmittance $(\lambda>70 \%)$ in the visible region and the transmittance of $(\mathrm{B}, \mathrm{Al}, \mathrm{Ga}$, In) doped $\mathrm{ZnO}$ thin film is in close proximity with undoped $\mathrm{ZnO}$ film. The decrease in the optical energy gap of the doped $\mathrm{ZnO}$ thin film is due to the variation in crystallite size. The XRD patterns demonstrate a large difference in angular positions between the undoped and group III elements doped $\mathrm{ZnO}$ thin films [13]. Mn doped $\mathrm{ZnO}$ thin film coated on glass substrate by spray pyrolysis technique. The stoichiometry of the film at $450^{\circ} \mathrm{C}$ was confirmed by RBS spectra and found to depend on the substrate temperature. By doping $\mathrm{Mn}$ in $\mathrm{ZnO}$, the wurtzite hexagonal structure remains unchanged. The maximum transmittance $100 \%$ was obtained for $\mathrm{ZnO}$ thin film at $500^{\circ} \mathrm{C}$, resulting in decrease in optical scattering. The bandgap energy values are $3.22 \mathrm{eV}$, $3.24 \mathrm{eV}$ and $3.27 \mathrm{eV}$ respectively for the films at $400^{\circ} \mathrm{C}, 450^{\circ} \mathrm{C}$ and $500^{\circ} \mathrm{C}$. The doping of Mn has no effects on the resistivity $\mathrm{ZnO}$ and $\mathrm{Mn}$ doped $\mathrm{ZnO}$ thin film [14]. Here we present the impact of substrate temperature on the structural, morphological, optical and magnetic properties of perfume spray deposited $\mathrm{ZnO}$ thin film. 


\section{Experimental details}

$\mathrm{ZnO}$ thin films were fabricated by spray technique using a perfume atomizer as reported $[15,16]$. The commercially available glass substrates $(75$ x $25 \mathrm{~mm}$ ) (Blue star Micro glass slides) were used for film deposition. The glass substrate was cleaned and degreased using distilled.water, HCL and acetone and dried. 0.1 $\mathrm{M}$ of Zinc acetate dihydrate, AR grade (SRL chemicals) is diluted with deionized water and ethanol in proportion 2:1. The solution is dispersed ultrasonically for its homogeneity and transparency for about 30 minutes. The solution was then sprayed onto the preheated glass substrate glass substrate maintained at $300^{\circ} \mathrm{C}, 350^{\circ} \mathrm{C}, 400^{\circ} \mathrm{C}$ and $450^{\circ} \mathrm{C}$ and is dried. Finally all the deposited films were annealed in a muffle furnace at $450^{\circ} \mathrm{C}$ for $2 \mathrm{hrs}$ under air atmosphere. The resultant $\mathrm{ZnO}$ thin films are well adherent to the substrate.

\subsection{Characterization techniques}

The crystallographic structure of $\mathrm{ZnO}$ thin film was studied by PANalytical/ Xpert3 powder Xray diffraction (XRD) instrument. The surface morphology of $\mathrm{ZnO}$ films were studied by FESEM (zeiss, Bruker instrument) and Atomic force microscope (Agilent 5500). Ultra-violet visible (UV-Vis) absorbance and transmittance measurements were conducted on UV-visible spectrophotometer (Thermofisher 220 instrument). Photoluminescence (PL) measurements were performed by Varian Cary Eclipse PL analyser. Room temperature Raman studies were conducted by micro Raman spectrometer SEKI, Japan. The magnetization (M) against applied field $(\mathrm{H})$ at room temperature was evaluated using Lake Shore, vibrating sample magnetometer (VSM).

\section{Results and Discussion}

\subsection{Structural characterization}


The XRD patterns of $\mathrm{ZnO}$ thin film deposited at various substrate temperatures and annealed at $450{ }^{\circ} \mathrm{C}$ were recorded over the $2 \theta$ range from $10^{\circ}-80^{\circ}$. Fig. 1 displayed the polycrystalline nature of the film, showing multiple peaks and indexed to the standard JCPDS card 89-1397, corresponding to hexagonal wurtzite structure. It belongs to $P 6_{3} m c$ space group. The high crystallinity of $\mathrm{ZnO}$ thin film is indexed by the presence of narrow and sharp reflection peaks [17]. The peaks at angle $2 \theta$ around $31.7^{\circ}, 34.24^{\circ}, 36.19^{\circ}, 47^{\circ}, 56^{\circ}, 62^{\circ}, 66^{\circ}, 67^{\circ}$ corresponds to (100), (002), (101), (102), (110), (103), (200), and (112) reflection planes. There are three prominent planes (100), (002), (101) at $2 \theta, 31.7^{\circ}, 34.24^{\circ}, 36.19^{\circ}$ and the weak reflection planes (102), (110), (103), (200), (112) and (201) at $2 \theta$ around $47^{\circ}, 56^{\circ}, 62^{\circ}, 66^{\circ}, 67^{\circ}$ are observed. No peak other than $\mathrm{ZnO}$ is observed within the detection limit. The as deposited and annealed $\mathrm{ZnO}$ thin films shown similar XRD pattern with intensity variation. The analogous results were reported by researchers $[18,19]$. The annealing resulted in better crystallinity and the oxidation of $\mathrm{ZnO}$ thin film fabricated at $300^{\circ} \mathrm{C}$ [20]. The observed variation in the peak intensity with the substrate temperature is due to different film thickness [21]. Further at $450^{\circ} \mathrm{C}$, the degree of crystallinity is deteriorated and the reflection of (002) plane is more pronounced confirmed the orientation along $c$ - axis perpendicular to the substrate [22,23] and this may lead to the granular structure of the film [24]. Hence, the reorientation of planes at $450^{\circ} \mathrm{C}$ is due to the lowest surface energy of the plane and internal stress at this temperature [25, 26]. Nitu kumara et al, reported the decrease in the intensity of $\mathrm{ZnO}$ thin film at higher substrate temperature. The decreasing trend was due to the incomplete conversion of Zinc precursor to $\mathrm{ZnO}$ [27]

The XRD parameter such as crystallite size (D), lattice strain $(\varepsilon)$ and dislocation density $(\delta)$ is found to decrease with substrate temperature. The decrease in the value of dislocation density $(\delta)$ 
implies the film has few lattice defects. The structural parameters, crystallite size (D), d-spacing, stress and strain, dislocation density $(\delta)$, volume of unit cell $(\mathrm{V})$, SSA are summarized in table 1.

The lattice parameters are evaluated using the following relation

$$
a=\frac{\lambda}{\sqrt{3} \sin \theta} ; c=\frac{\lambda}{\sin \theta}
$$

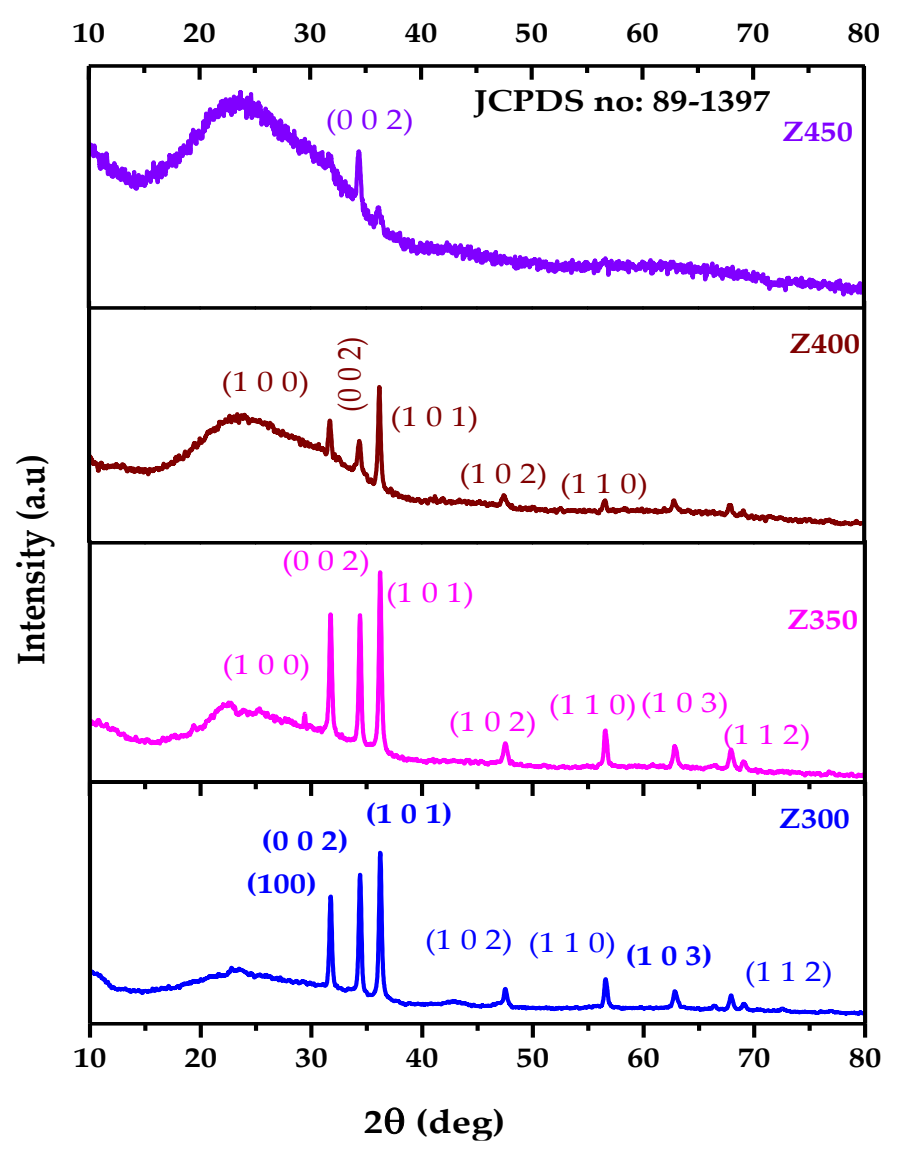

Fig 1. XRD patterns of annealed $\mathrm{ZnO}$ thin film at different substrate temperature 
The lattice strain $(\varepsilon)$ and the stress $(\sigma)$ in the film is calculated using the expression

$$
\begin{gathered}
\varepsilon=\frac{c-c_{0}}{c_{0}} \times 100 \% \\
\sigma=-4.5 \times 10^{11} * \varepsilon
\end{gathered}
$$

The unit cell volume (V) was estimated from

$$
V=\frac{\sqrt{3}}{2} a^{2} c
$$

The crystallite size of (101) plane at substrate temperature $300^{\circ} \mathrm{C}, 350^{\circ} \mathrm{C}$, and $400^{\circ} \mathrm{C}$ are estimated as $48.96 \mathrm{~nm}, 40.61 \mathrm{~nm}$ and $35.66 \mathrm{~nm}$ respectively and the crystallite size of (002) plane at $450^{\circ} \mathrm{C}$ is $24.14 \mathrm{~nm}$ expressing the microstructural character of deposited $\mathrm{ZnO}$ film. The crystallite size (D) of intense (101) plane is found to decrease with substrate temperature. Likewise the full width half maximum $(\beta)$ decreases with substrate temperature. The higher the crystallite size $(D)$, lower the dislocation density $(\delta)$ [28]. The negative sign in stress values represents the compressive stress in $\mathrm{ZnO}$ thin films. The variation in lattice parameter ' $a$ ' and 'c' are related to $\mathrm{a}_{0}$ and $\mathrm{c}_{0}$ [29]. 
Table:1 XRD parameters FWHM, crystallite size (D), strain , stress , d-spacing, lattice constant a and c and volume of unit cell, specific surface area.

\begin{tabular}{|c|c|c|c|c|c|c|c|c|c|c|c|}
\hline $\begin{array}{c}\text { Substrate } \\
\text { temperature } \\
(\mathrm{deg})\end{array}$ & $\begin{array}{c}2 \theta \\
(\mathrm{deg})\end{array}$ & $\begin{array}{c}\text { (hkl) } \\
\text { plane }\end{array}$ & $\begin{array}{c}\text { Crystallite } \\
\text { Size D } \\
(\mathrm{nm})\end{array}$ & $\begin{array}{c}\text { Dislocation } \\
\text { density } \\
\delta \times 10^{-14} \\
l / \mathrm{m}^{2}\end{array}$ & Strain & $\begin{array}{c}\text { Stress } \\
\mathrm{x} 10^{10} \\
\mathrm{Nm}^{-2}\end{array}$ & $\begin{array}{c}\mathrm{d}- \\
\text { spacing } \\
(\AA)\end{array}$ & $\begin{array}{c}\mathrm{a} \\
(\AA)\end{array}$ & $\begin{array}{c}\mathrm{V} \\
(\AA)\end{array}$ & $\begin{array}{c}\text { SSA } \\
(\AA)\end{array}$ \\
\hline 300 & 36.25 & 101 & 48.96 & 4.171 & -0.0491 & 2.209 & 2.476 & 2.858 & 4.950 & 35.014 & 21.663 \\
\hline 350 & 36.08 & 101 & 40.61 & 6.063 & -0.0449 & 2.020 & 2.479 & 2.871 & 4.972 & 35.490 & 26.117 \\
\hline 400 & 36.08 & 101 & 35.66 & 7.863 & -0.0449 & 2.020 & 2.483 & 2.871 & 4.972 & 35.490 & 29.742 \\
\hline 450 & 34.36 & 002 & 24.14 & 17.160 & 0.0013 & -0.058 & 2.608 & 3.010 & 5.213 & 40.901 & 43.936 \\
\hline
\end{tabular}




\subsection{FESEM analysis}

The surface microstructures of $\mathrm{ZnO}$ thin films at different magnifications are displayed in Fig 2 (a-h). The increase in substrate temperature and annealing has influenced $\mathrm{ZnO}$ thin film. The $\mathrm{ZnO}$ film showing different morphology at various substrate temperatures and random orientation are obtained [30]. Fig.2 (a,c,e) showed the wrinkled shaped fibrous structure with porous, spherical granules are randomly distributed over uniformly layer of $\mathrm{ZnO}$ thin film deposited at $300^{\circ} \mathrm{C}$, $350^{\circ} \mathrm{C}$ and $400^{\circ} \mathrm{C}$ which is due to the influence of temperature between first layer and the other layer of the $\mathrm{ZnO}$ [22]. The fibrous structure formation is due to slow cooling. During cooling, the ions may have sufficient time to aggregate along crystal planes with similar lattice match. This fibrous like morphologies have large surface area shown in Table:1, that it may be used for optoelectronic devices and photovoltaic devices application [24]. Some voids are observed in between the nanostructures through which oxygen and water molecule propagates into the $\mathrm{ZnO}$ thin film [31-33]. The energy gained due to annealing merge the grain boundaries with each other forming larger grains [34].The fiber like morphology switched to the surface having spherical shaped grains with high inter grain spacing at higher substrate temperature $450^{\circ} \mathrm{C}[15,35]$. The uniform distribution of spherical grains can be obtained using acetate precursor as reported by Harish Bahadur et.al. [36]. 


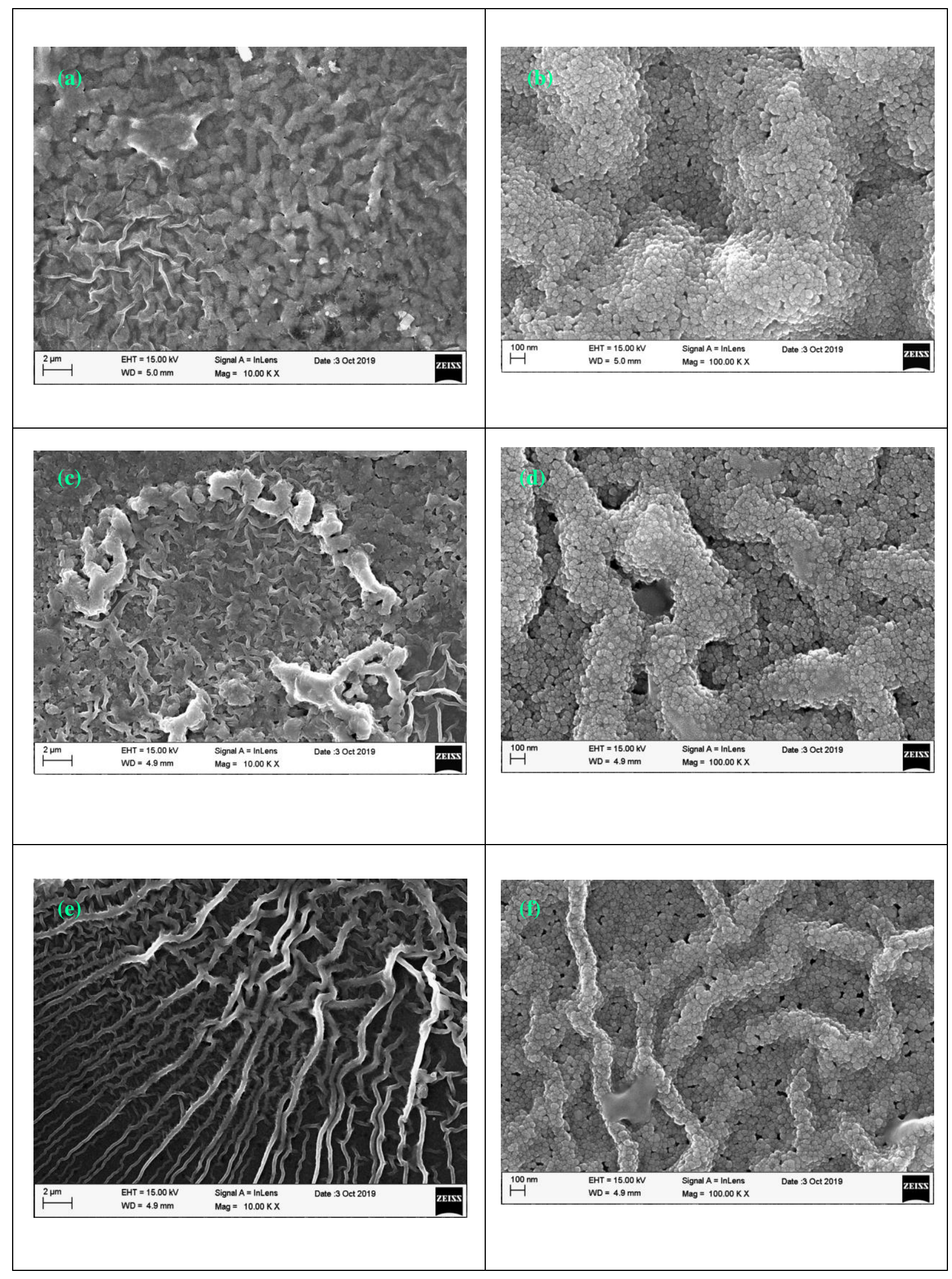




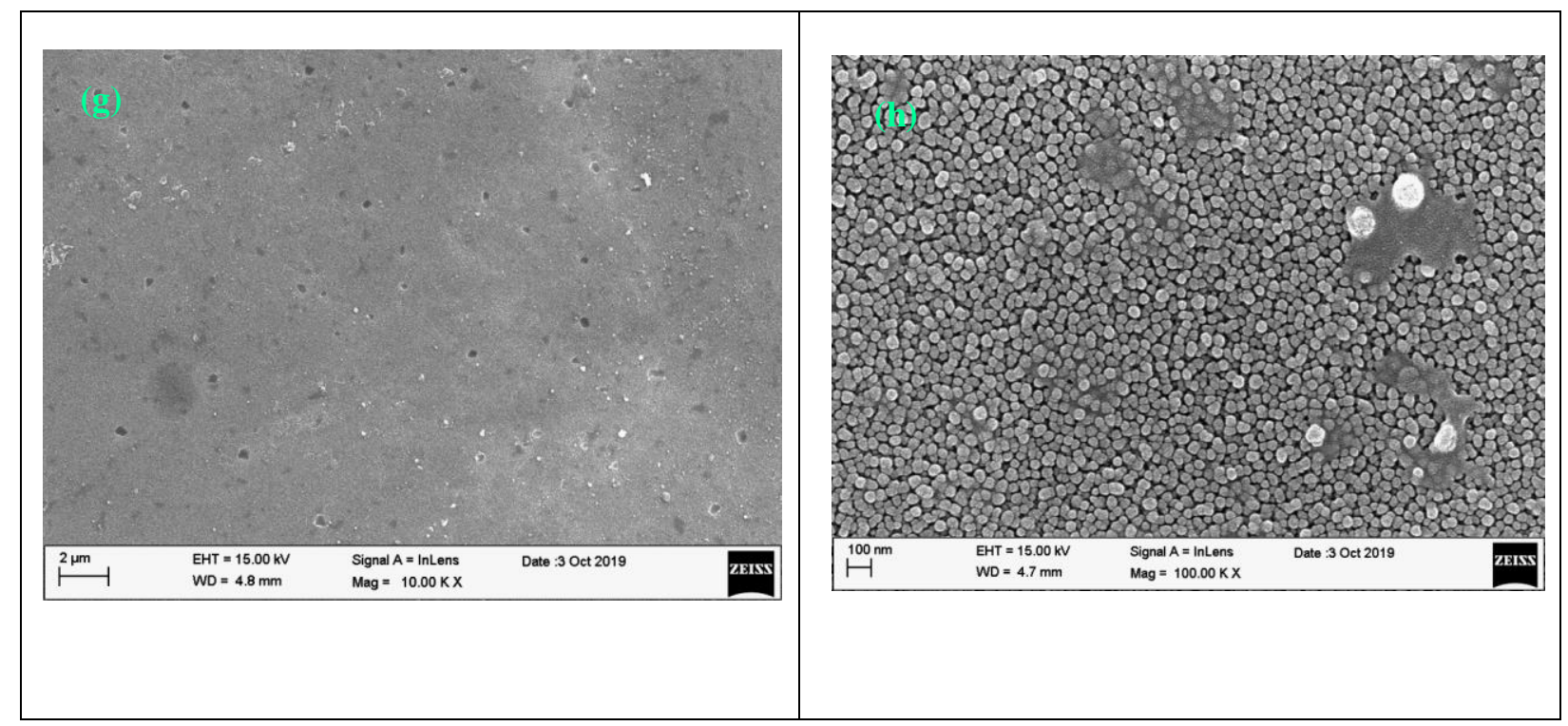

Fig. 2 FE-SEM images of $\mathrm{ZnO}$ thin films at substrate temperature (a,b) $300^{\circ} \mathrm{C}$, (c,d) $350^{\circ} \mathrm{C}$, (e,f) $400^{\circ} \mathrm{C}$ and $(\mathrm{g}, \mathrm{h}) 450^{\circ} \mathrm{C}$

\subsection{EDS micro elemental analysis}

Fig. 3(b,d,f,h) shows EDS spectra of $\mathrm{ZnO}$ thin film at different substrate temperatures and the presence of $\mathrm{Zn}$ and $\mathrm{O}$ is confirmed. The EDS results depicts that none of the samples are well stoichiometric. The $\mathrm{Zn}$ distribution $(\%)$ in the grown structure decreases with substrate temperature might be due to the lower density of nucleated $\mathrm{ZnO}$. And as a result increasing trend in $\mathrm{O}(\%)$ is ascribed to the oxygen incorporation during spray deposition $[37,38]$. 


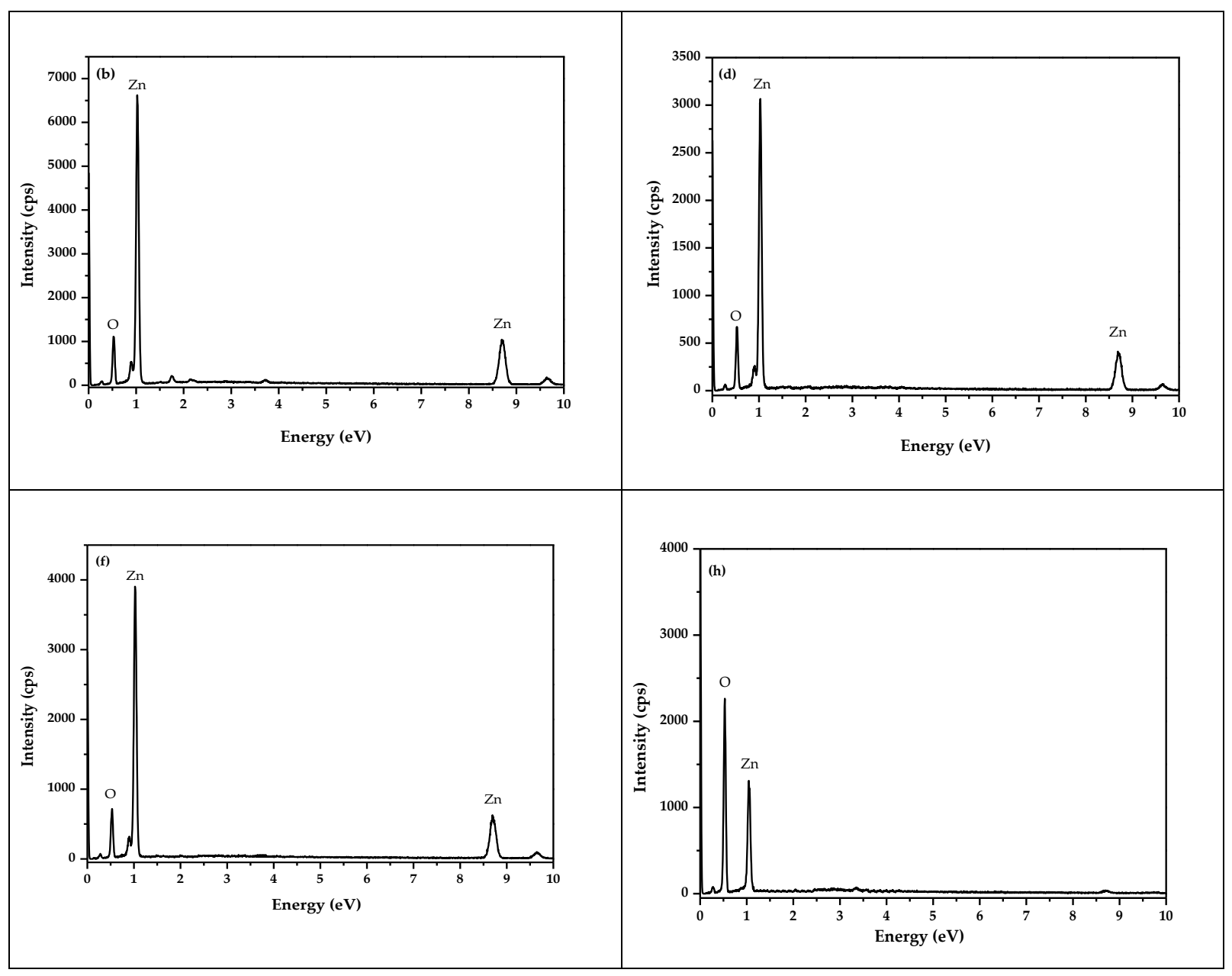

Fig. 3 EDS spectra of $\mathrm{ZnO}$ film at substrate temperatures

\subsection{AFM Analysis}

The surface microstructure of $\mathrm{ZnO}$ film deposited on glass substrate at various substrate temperatures are analyzed from AFM measurements. The Fig. $4(\mathrm{a}-\mathrm{h})$, depicts the 2D and 3D profile images of $\mathrm{ZnO}$ thin film. The micro structural images are on par with the FE-SEM morphologies. The surface roughness is minimum and maximum for the film at lower $\left(300^{\circ} \mathrm{C}\right)$ and higher substrate temperature $\left(450^{\circ} \mathrm{C}\right)$. At temperatures between $300^{\circ} \mathrm{C}$ and $450^{\circ} \mathrm{C}$, the different surface morphologies like wrinkle shaped and spherical grains are obtained. Fig. 4(c) 
illustrates columnar shaped grains perpendicular to the substrate surface showing wrinked appearance [39].

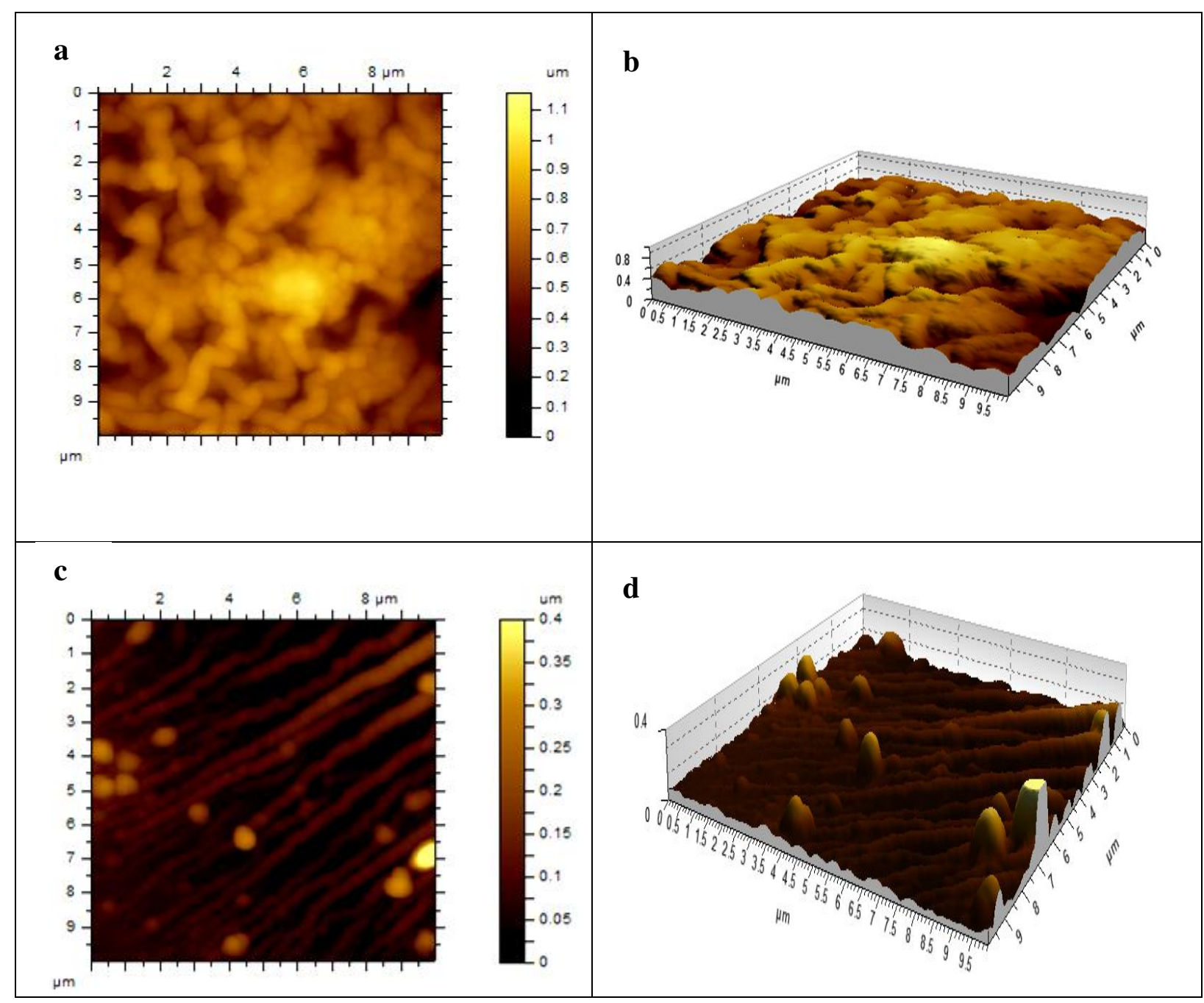




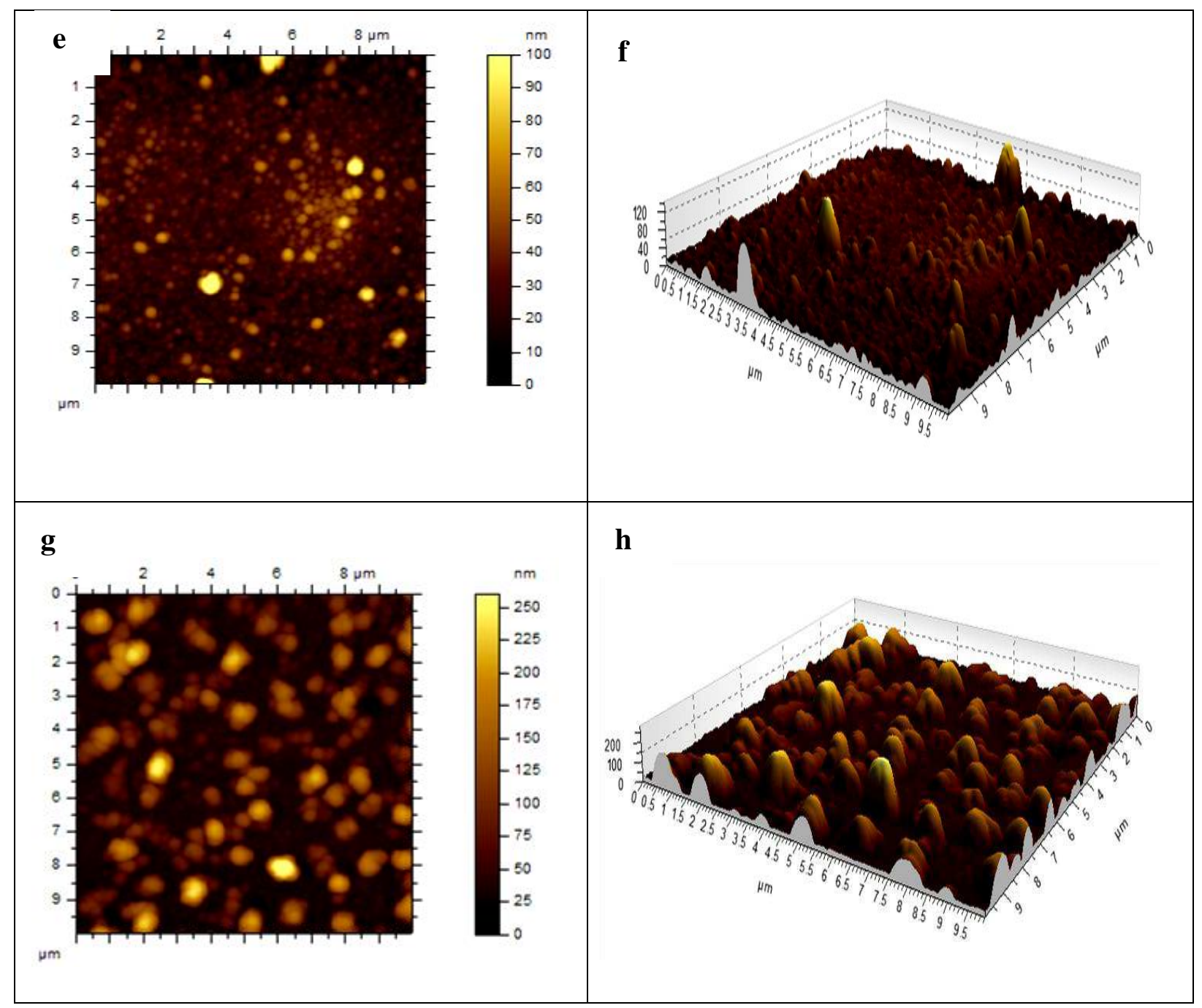

Fig. 4 (a - h), 2D and 3D AFM image of $\mathrm{ZnO}$ thin film at different substrate temperatures.

\subsection{Optical characterization}

The UV-Vis absorbance and transmittance spectra of $\mathrm{ZnO}$ film deposited at different substrate temperature were recorded over wavelength range $200-1100 \mathrm{~nm}$, is displayed in Fig.5. The presence of two absorption peaks at around $316 \mathrm{~nm}$ and $360 \mathrm{~nm}$ for all the film are identified. The absorption peak around $316 \mathrm{~nm}$ refers to the excitonic absorption. This excitonic absorption peak lies significantly below the $360 \mathrm{~nm}$ i.e, the band gap of $\mathrm{ZnO}$, is associated with the quality 
of nanoparticle distribution [40]. The strong absorption peak around $360 \mathrm{~nm}$ is the characteristic of $\mathrm{ZnO}$ film. All the films shows high optical transparency of $\geq 80 \%$ in visible region, which is one of the prime requirement for device applications such as optoelectronic and solar cell application and low transparency in the UV region. The high transmittance of $\mathrm{ZnO}$ thin film emphasize that the film is neither absorbed nor scattered the light [41]. The absence of interference fringes in the transmittance spectra is correlated to diffusion phenomena and small grain size of the deposited films [9, 42].

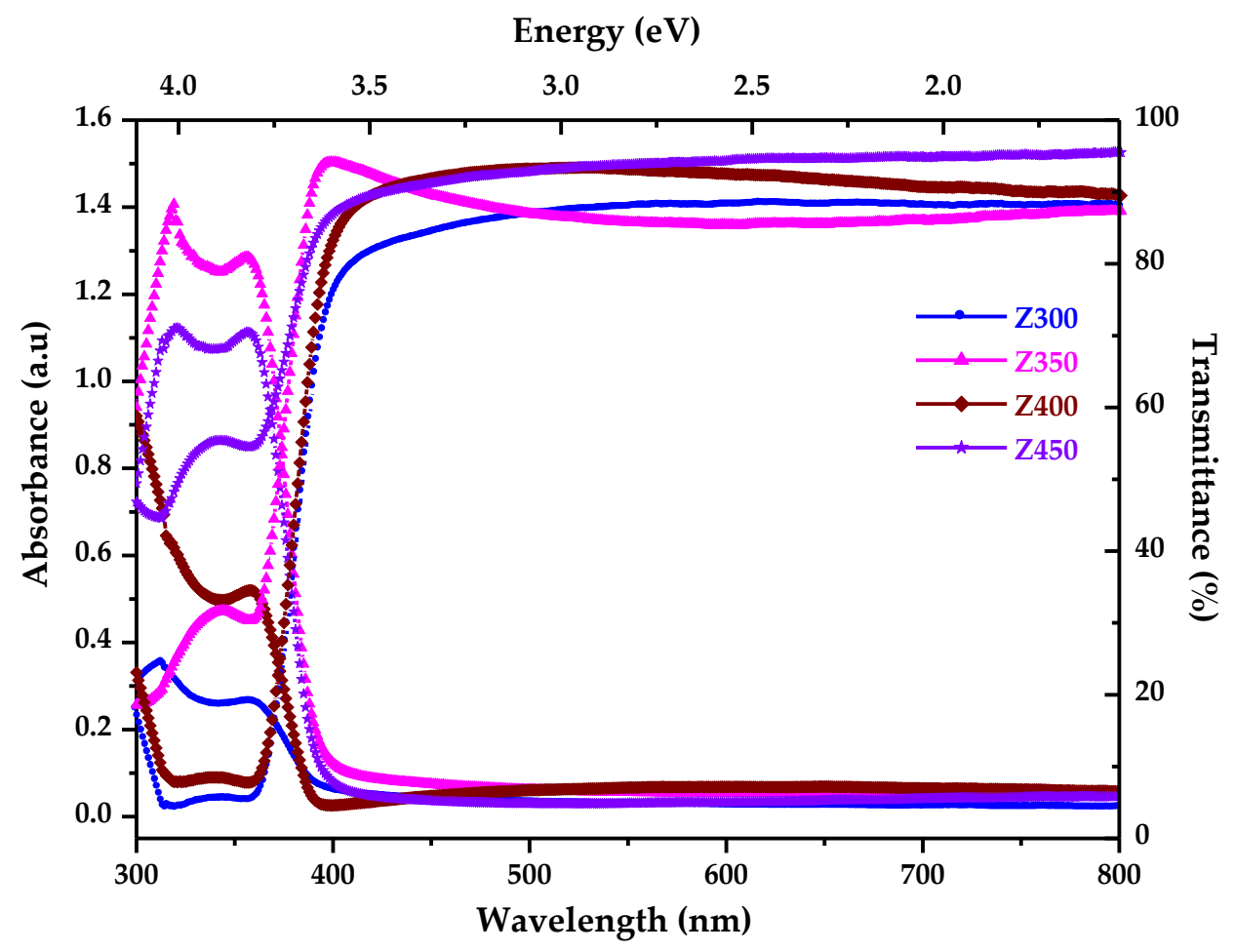

Fig.5 UV Vis absorbance and transmittance spectra of $\mathrm{ZnO}$ thin film

The transmittance drops appreciably around $370 \mathrm{~nm}$ in UV region and it is the intrinsic band gap of $\mathrm{ZnO}$ film (3.3 eV). The shift in absorption edge towards lower wavelength regime for the film deposited at various substrate temperatures is displayed. It is observed for all the film, the transmittance decreases below $400 \mathrm{~nm}$, is due to the fundamental absorption edge attributed to 
the electron, that makes cross over from valance band to conduction band. The change in optical transmittance of the film is related to surface roughness and the virtue of crystallinity of $\mathrm{ZnO}$ film [9]. The blue shift is identified for the $\mathrm{ZnO}$ film deposited at $450^{\circ} \mathrm{C}$ and hence the particle is confined to the quantum level. Generally, the quantum size effect occurs for the particles upto 8 $\mathrm{nm}[43,44]$ and in our case, the crystallite size of the $\mathrm{ZnO}$ film is above the expected quantum confined size.

The relation used for manipulating the absorption coefficient is given by the formula,

$$
\alpha=\frac{2.303}{t} A=\frac{1}{t} \ln \frac{1}{T}
$$

where $\mathrm{d}$ is the thickness of the film, $\mathrm{A}$ and $\mathrm{T}$ are the absorbance and transmittance of the film deposited. The absorption coefficient of $\mathrm{ZnO}$ film is displayed in the Fig: 6. The absorption coefficient varies exponentially with incident photon energy near absorption edge and obeys urbach relation [41].

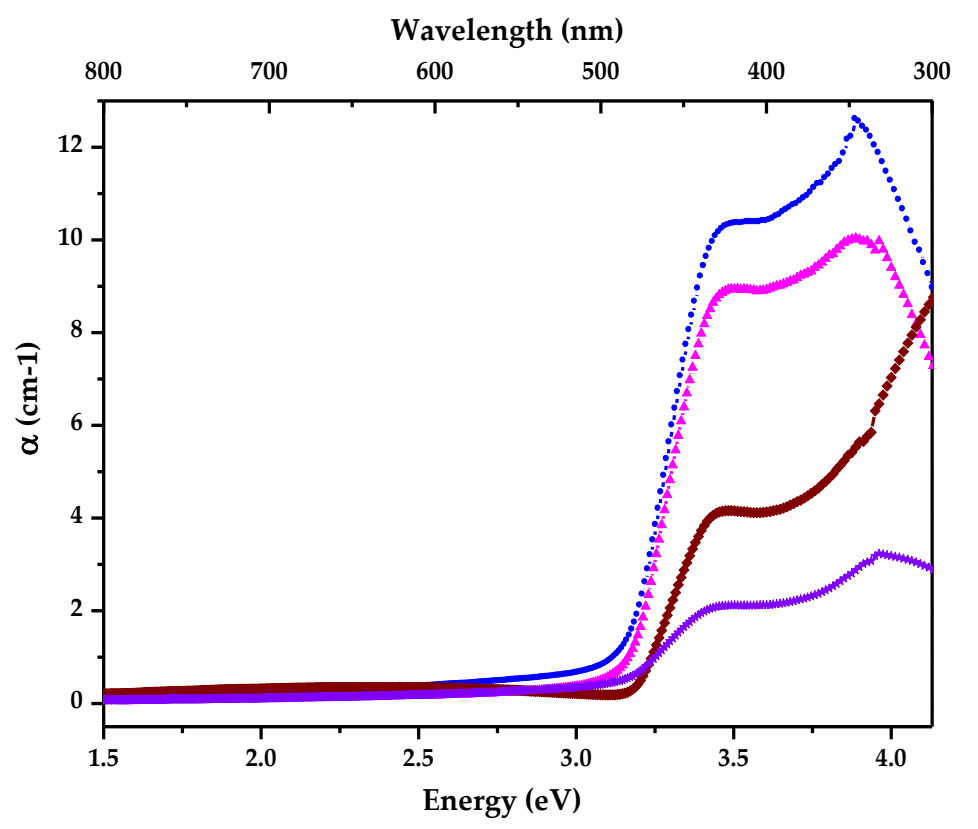

Fig 6. Absorption coefficient Vs Wavelength plot of $\mathrm{ZnO}$ film 
The band gap for $\mathrm{ZnO}$ film estimated from the Tauc's plot is displayed in Fig 7.

The optical band gap $\mathrm{E}_{\mathrm{g}}$ was estimated from the relation

$$
(\alpha h v)^{2}=A\left(h v-E_{g}\right)
$$

where ' $\mathrm{A}$ ' is the proportionality constant, ' $\mathrm{Eg}_{\mathrm{g}}$ ' is the direct band gap, ' $\mathrm{h} v$ ' is the incident photon energy and ' $\alpha$ ' is the absorption coefficient.
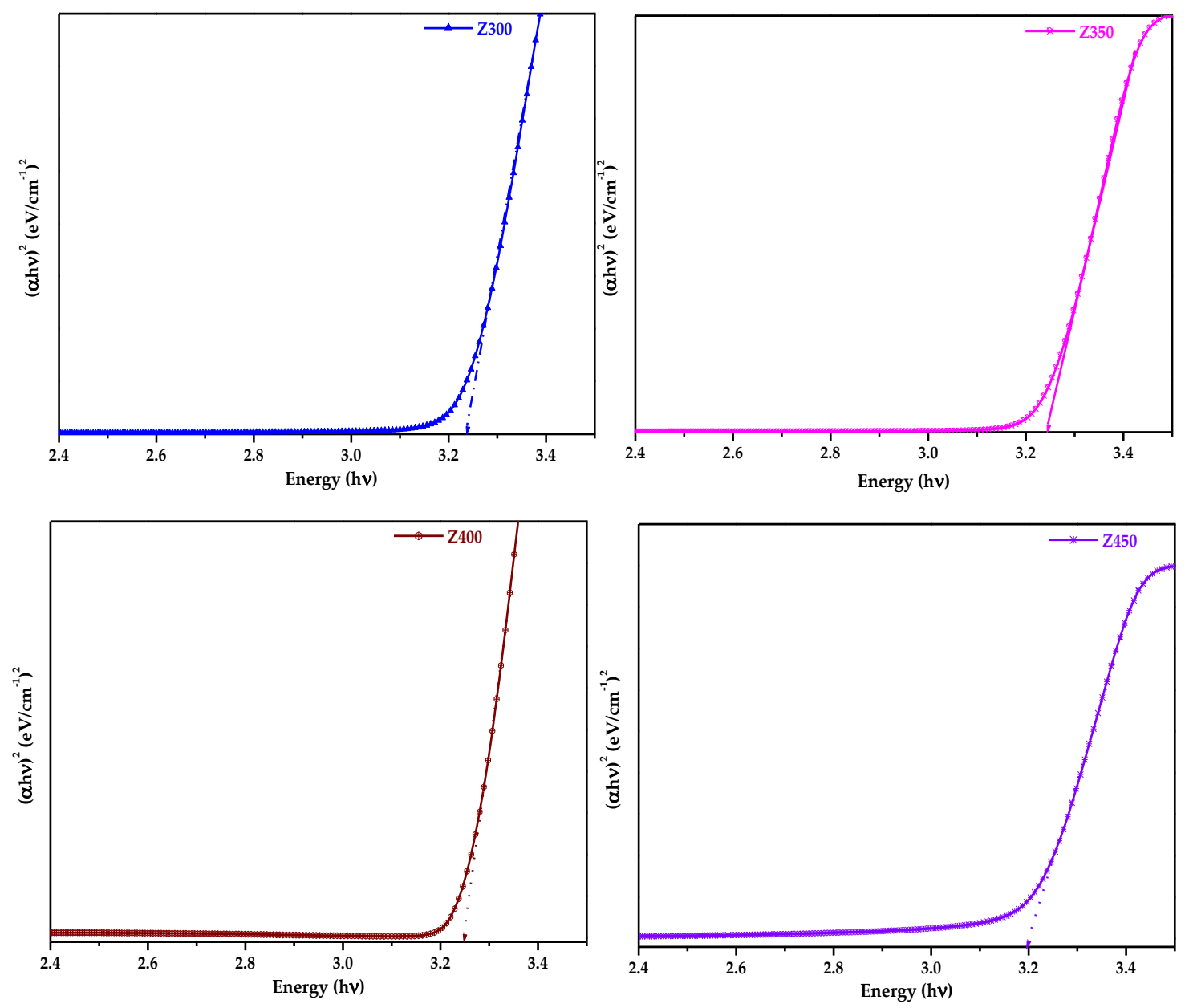

Fig 7. Tauc plot of $\mathrm{ZnO}$ film at substrate temperature (a) $300^{\circ} \mathrm{C}$ (b) $350^{\circ} \mathrm{C}$, (c) $400^{\circ} \mathrm{C}$ and (d) $450^{\circ} \mathrm{C}$.

A graph plotted between $(\alpha h v)^{2}$ and $h v$ and the optical band gap is derived by extrapolating the linear portion of $(\alpha h v)^{2}$ tohv. The linearity noticed from the graph represents the direct 
transition of band gap of the semiconductor. The band gap of $\mathrm{ZnO}$ thin film ranged from 3.24 $3.19 \mathrm{eV}$. The film deposited at substrate temperature $450{ }^{\circ} \mathrm{C}$ was $3.19 \mathrm{eV}$. And this trend in band gap may be due to the appearance of band tail from defects and surface roughness [28]. The decrease in the optical band gap as the function of annealing temperature is associated with the interatomic distance [45]. The observed band gap value is in good agreement with the earlier reports $[46,47]$.

The refractive index (n) was calculated using following equation.

$$
n=\frac{1+R}{1-R}+\sqrt{\frac{4 R}{(1-R)^{2}}-k^{2}}
$$

The extinction coefficient is evaluated using the relation

$$
k=\frac{\alpha \lambda}{4 \pi}
$$

The spectral variation in extinction coefficient as a function of wavelength is displayed in the Fig

9.

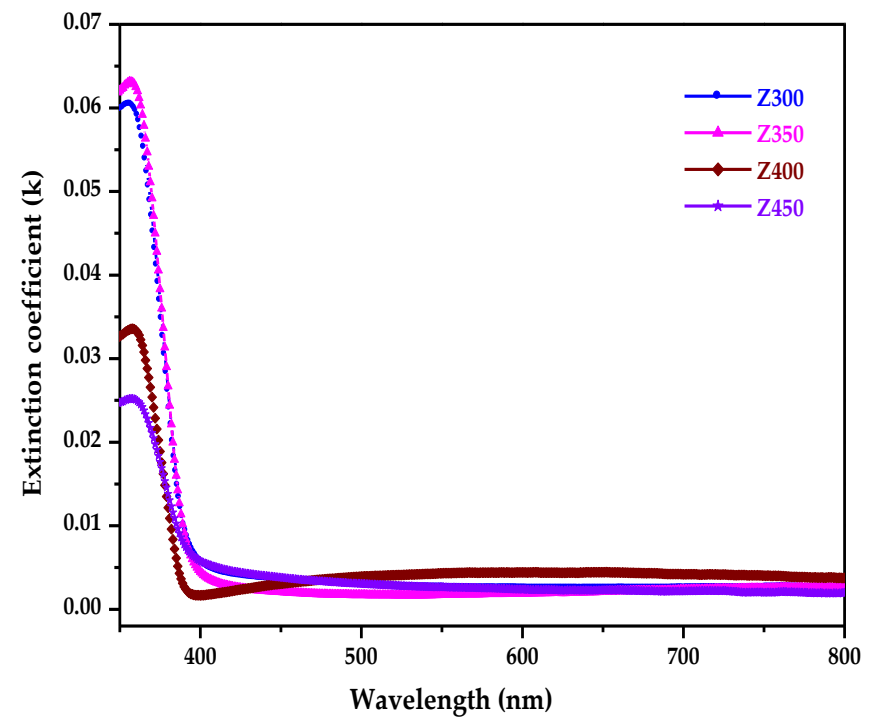

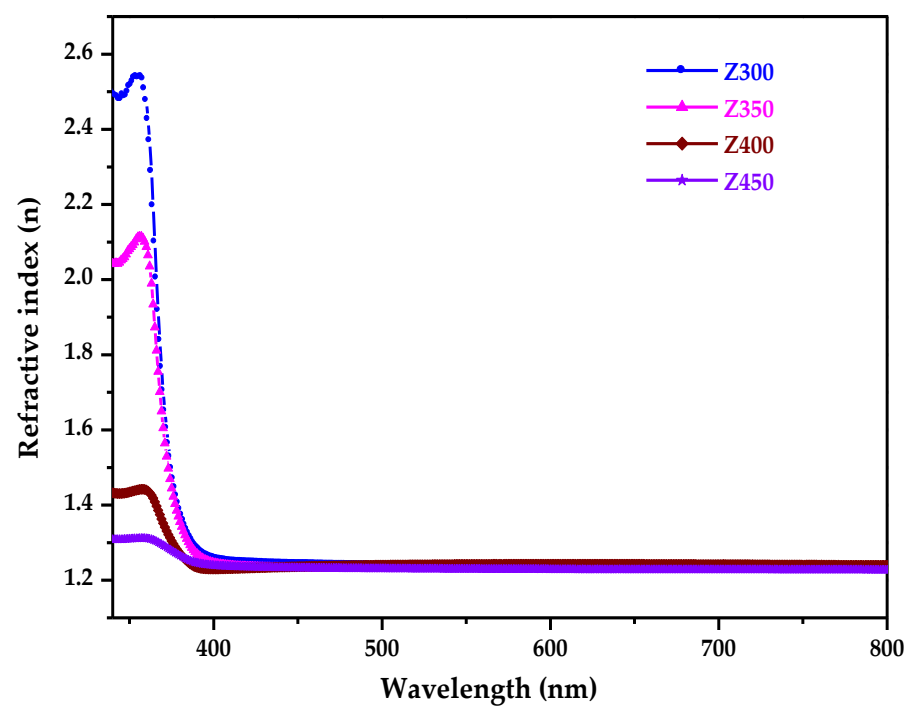

Fig 8. Variation of extinction coefficient and Refractive index with wavelength of $\mathrm{ZnO}$ film 
The extinction coefficient $(k)$ shows decreasing trend with increase in deposition temperature, whereas the $\mathrm{ZnO}$ thin film deposited at $400{ }^{\circ} \mathrm{C}$ have increasing behavior [34]. From Fig. $8 \& 9$, the refractive index (n) and extinction coefficient $(k)$ decreases with increase in wavelength is observed, is associated with light scattering. The value of refractive index (n) and extinction coefficient $(k)$ in visible region is low with that of the theoretical value, accumulating that the $\mathrm{ZnO}$ thin film has low dielectric loss [48].

\subsection{Photoluminescence Characterization}

The room temperature photoluminescence spectra of $\mathrm{ZnO}$ film deposited at different substrate temperature is recorded and presented in Fig. 10.

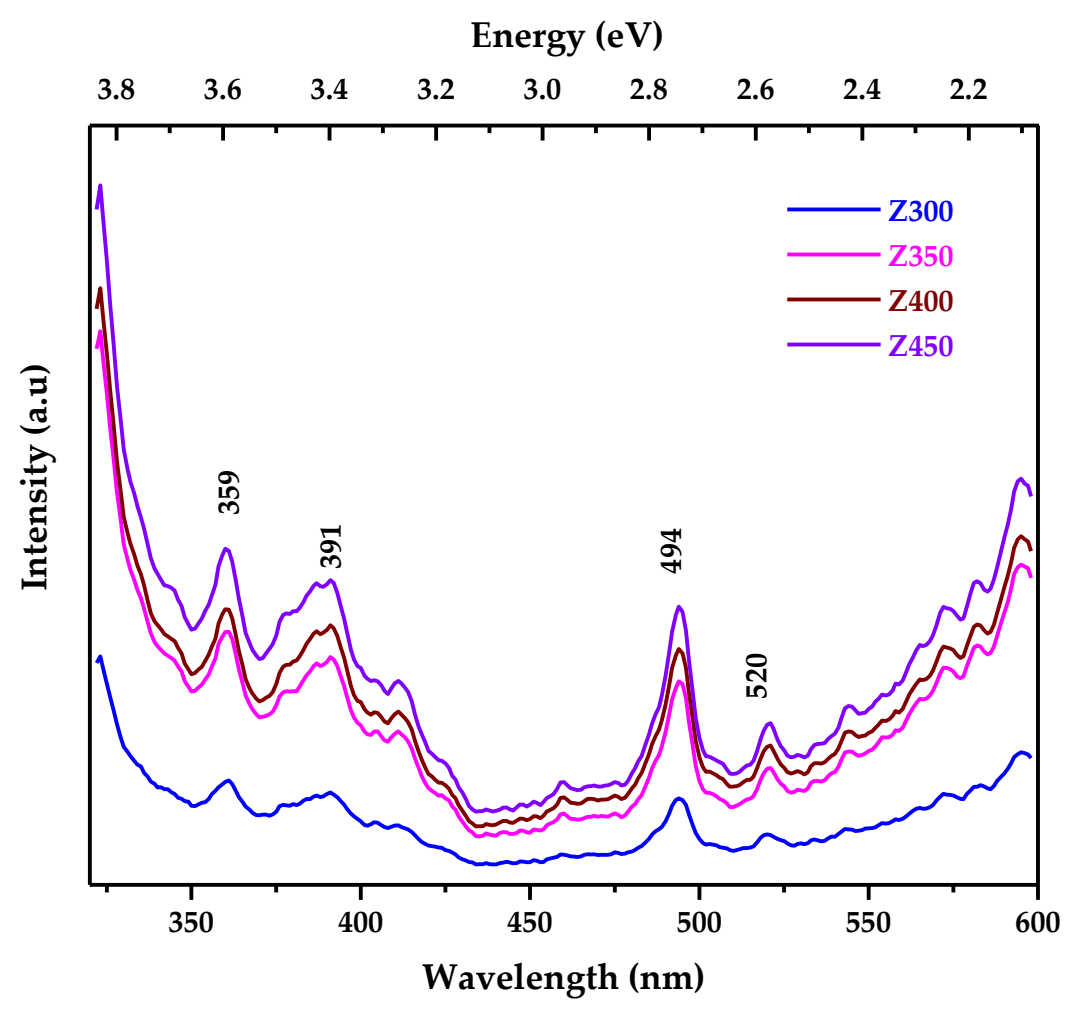

Fig: 10 Room temperature PL spectra of $\mathrm{ZnO}$ thin film

The PL spectra of $\mathrm{ZnO}$ film were recorded in the wavelength range $300-600 \mathrm{~nm}$ with excitation wavelength of $320 \mathrm{~nm}$. The different forms of $\mathrm{ZnO}$, such as nano particle, thin film, nano rod, nano sheet etc, manifests two luminescence band, (i) short wavelength band, near the absorption 
edge and (ii) long wavelength band, usually in visible green region [49]. As seen from the spectra, $\mathrm{ZnO}$ thin film consists of five luminescence peaks at wavelength 360, 390, 411, 494 and $520 \mathrm{~nm}$. The strong peak at $359 \mathrm{~nm}$ is due to free exciton (FE) [50] and the $390 \mathrm{~nm}$ peak $(3.17$ $\mathrm{eV}$ ) corresponds to excitonic emission from near band edge transition of wide band gap of $\mathrm{ZnO}$, i.e, the recombination of excitons through exciton - exciton collision process [51]. The strong band edge transition found to be red shifted compared to the bulk $\mathrm{ZnO}$. This shift is referred to the change in optical band gap of $\mathrm{ZnO}$ film [52]. For pure $\mathrm{ZnO}$, defects such as zinc interstitials $\left(\mathrm{Zn}_{\mathrm{i}}\right)$ and oxygen vacancies $\left(\mathrm{V}_{\mathrm{o}}\right)$ contributes to PL emission. Also, the emission around $400-$ $560 \mathrm{~nm}$ wavelength region contains distinct peaks at $411 \mathrm{~nm}(3.01 \mathrm{eV}), 494 \mathrm{~nm}(2.51 \mathrm{eV})$ and $520 \mathrm{~nm}(2.38 \mathrm{eV})$ originates single/double ionized oxygen vacancy which activate bound magnetic polarons in dilute magnetic semiconductors (DMS) [53, 54]. The violet emission at 411 $\mathrm{nm}$ is related to $\mathrm{Zn}$ vacancies. The luminescence centered at $494 \mathrm{~nm}$ is assigned to as deep level emission (DLE), that arises due to recombination of a photogenerated hole with electron which is the native defects in the surface and sub surface such as oxygen vacancies, $\mathrm{Zn}$ interstitials, lattice defects etc., of $\mathrm{ZnO}$ [55]. The emission peak $520 \mathrm{~nm}$ is due to the transition from conduction band to oxygen antisite level [56]. The strong emission in blue - green region indicates that it could be used in LED application [57].

\subsection{Raman characterization}

Raman spectroscopy is a powerful non destructive characterization technique for the study of structural properties of oxides. Raman spectra arise from the inelastic scattering of light, mostly in visible region. The $\mathrm{ZnO}$ belongs to wurzite structure with $C_{6 v}^{4}$ symmetry. The representation of brillouin zone is as follows, 


$$
\Gamma_{o p}=2 A_{1}+2 B_{1}+2 E_{1}+2 E_{2}
$$

Where $\mathrm{A}$ and $\mathrm{B}$ modes presents one fold degeneracy, E modes are twofold degeneracy. For $\mathrm{ZnO}$, there are 12 phonon branches, of which 9 optical and 3 acoustical phonon modes [57]. The Raman spectra of $\mathrm{ZnO}$ film is shown in Fig.11.

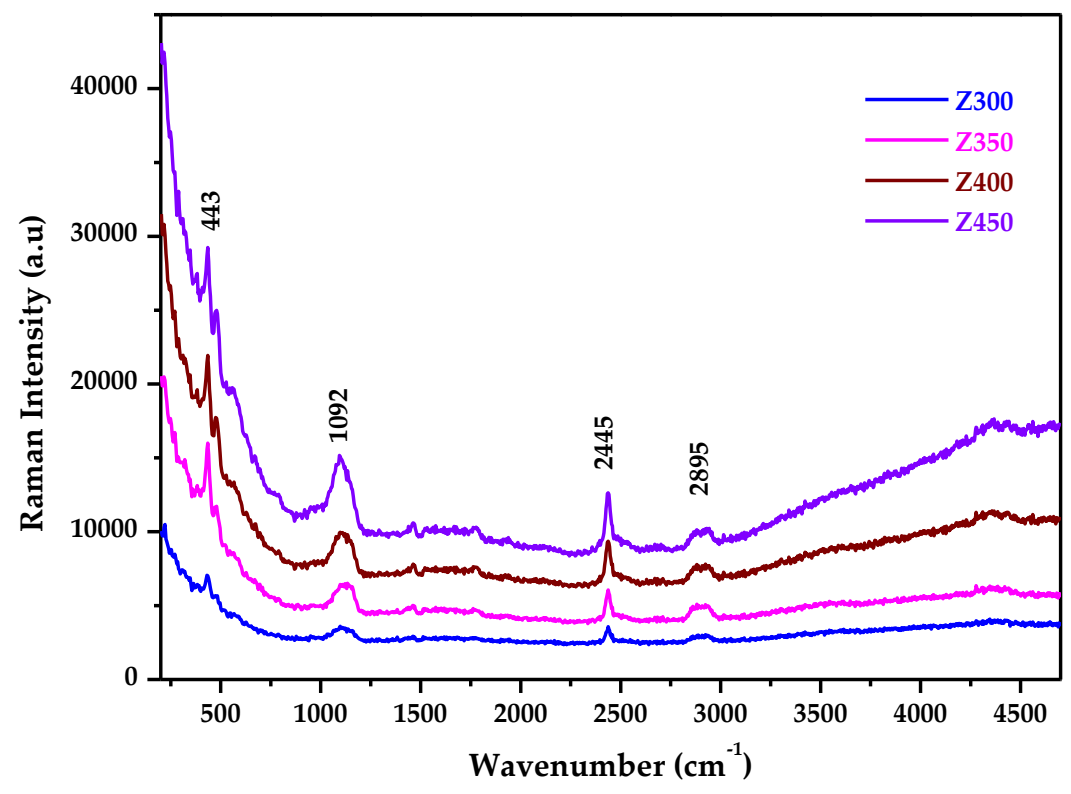

Fig 11. RT Raman Spectra of ZnO thin film

The frequency below $500 \mathrm{~cm}^{-1}$ is assigned for transverse acoustical vibrations mode is and the frequency region between 500 and $1300 \mathrm{~cm}^{-1}$ related to longitudinal optical modes. For $\mathrm{ZnO}, \mathrm{B}_{1}$ modes are silent and are Raman inactive. The high frequency $E_{2}^{\text {high }}$ mode at $438 \mathrm{~cm}^{-1}$ is associated to oxygen atoms, is the characteristics of wurtzite phase [58]. The shift in $E_{2}^{\text {high }}$ peak is observed for the film deposited at $400{ }^{\circ} \mathrm{C}$ and $450{ }^{\circ} \mathrm{C}$ which account for the intrinsic defect present in the film [59]. The A broad hump around $564 \mathrm{~cm}^{-1}$ corresponds to multiple phonon (M) vibration. It is observed that $\mathrm{E}_{1}$ mode does not appear for $\mathrm{ZnO}$ thin film, favoring the growth of $\mathrm{ZnO}$ thin film along c- axis. The peak observed at $1110 \mathrm{~cm}^{-1}$ and $2890 \mathrm{~cm}^{-1}$ corresponds to A1 
(2LO) mode and organic residue $\left(\mathrm{CH}_{3}\right.$ stretching), (does not decompose completely) respectively $[60]$.

\subsection{Magnetic Characterization}

The magnetic properties of perfume sprayed $\mathrm{ZnO}$ thin film at different substrate temperature $300^{\circ} \mathrm{C}, 350^{\circ} \mathrm{C}, 400^{\circ} \mathrm{C}$ and $450^{\circ} \mathrm{C}$ were measure at room temperature by vibrating sample magnetometer (VSM), Lake shore. The magnetization $(\mathrm{M})$ versus applied magnetic field $(\mathrm{H})$ is displayed in Fig:12

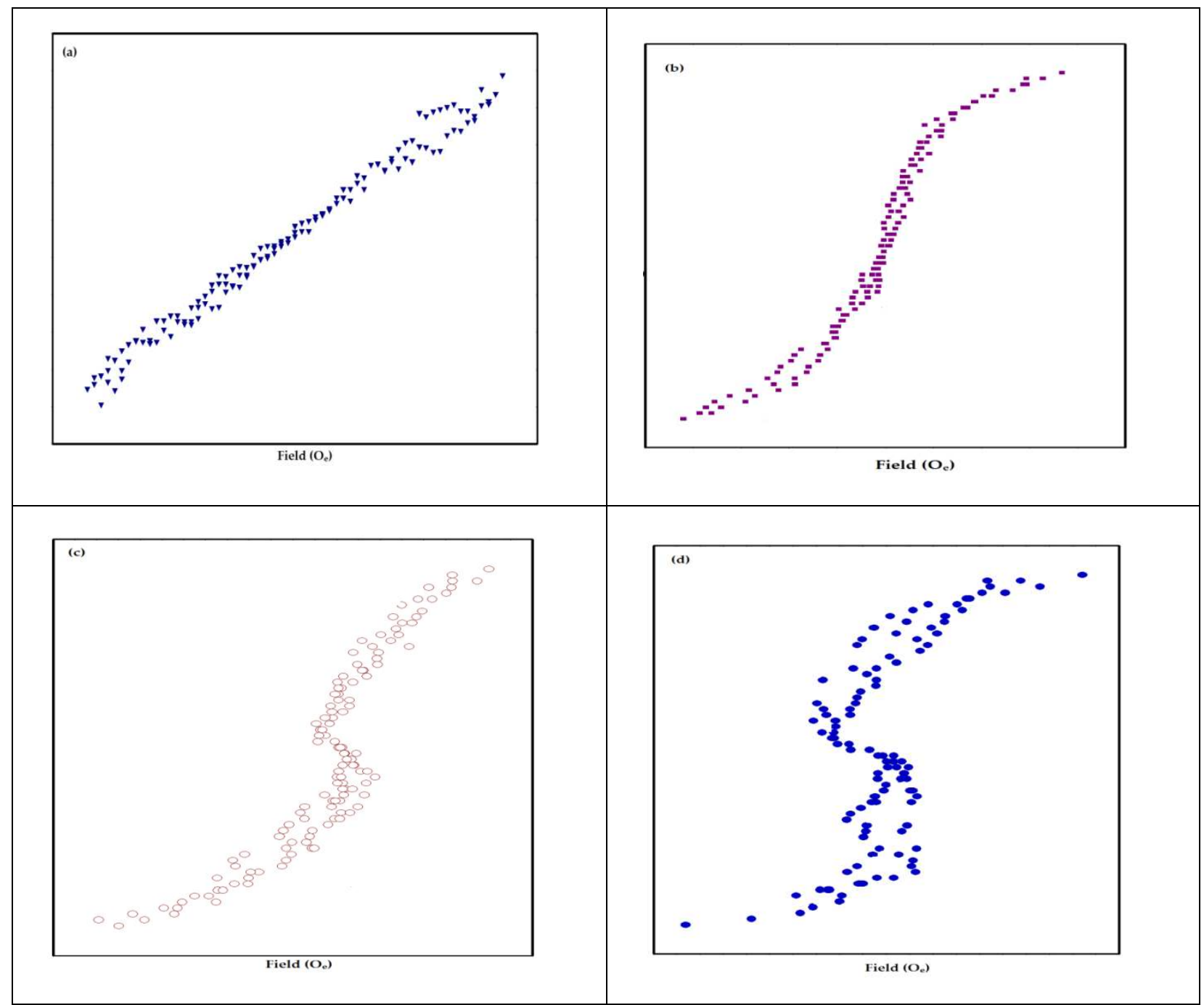

Fig: $12 \mathrm{M}-\mathrm{H}$ plot for $\mathrm{ZnO}$ thin film at (a) $300^{\circ} \mathrm{C}$, (b) $350^{\circ} \mathrm{C}$, (c) $400^{\circ} \mathrm{C}$ and (d) $450^{\circ} \mathrm{C}$ 
The presence of weak magnetic signal is observed from the Fig and it may be rooted from defects induced in the film [62]. The coercivity $(\mathrm{H})$ increases with substrate temperature and then decreases, while the saturation and remnant magnetization $\left(\mathrm{M}_{\mathrm{s}}\right)$ decreases. The decrease in saturation magnetization resulted in an increase in coercivity is observed [63]. The ratio $\left[\frac{M_{r}}{M_{s}}\right]$ is the measure of squareness (i.e,) square of hysteresis loop. The squareness ratio is relatively close to zero $[64,65]$ and are tabulated in Table: 3 .

Table:3 Magnetic properties of $\mathrm{ZnO}$ thin film

\begin{tabular}{|l|l|l|l|c|l|}
\hline Samples & $\begin{array}{c}\text { Retentivity } \\
(\mathrm{emu})\end{array}$ & $\begin{array}{c}\text { Coercivity } \\
\left(\mathrm{O}_{\mathrm{e}}\right)\end{array}$ & $\begin{array}{l}\text { Saturation } \\
\text { magnetization } \\
\left(\mathrm{M}_{\mathrm{s}}\right)\end{array}$ & $\begin{array}{c}\text { Squareness ratio } \\
\frac{M_{r}}{M_{s}}\end{array}$ & $\begin{array}{c}\text { Exchange bias } \\
\frac{H_{c}}{2}\end{array}$ \\
\hline $\mathrm{Z} 300$ & $6.98 \times 10^{-6}$ & 518 & $220.6 \times 10^{-6}$ & 0.031 & 259 \\
\hline $\mathrm{Z} 350$ & $4.26 \times 10^{-6}$ & 1274 & $196.8 \times 10^{-6}$ & 0.021 & 637 \\
\hline $\mathrm{Z} 400$ & $0.39 \times 10^{-6}$ & 1934 & $89.5 \times 10^{-6}$ & 0.004 & 967 \\
\hline $\mathrm{Z} 450$ & $3.99 \times 10^{-6}$ & 414 & $85.1 \times 10^{-6}$ & 0.046 & 207 \\
\hline
\end{tabular}

The bulk $\mathrm{ZnO}$ is diamagnetic [66] and in our case the magnetization in $\mathrm{ZnO}$ thin film arises due to defects such as cation $(\mathrm{Zn})$ vacancies, preparation methods and microstructure $[67,68]$. Ferromagnetic behavior observed in metal oxides (pure) is been reported by many researchers $[69,70]$. Also, the oxide thin film does not require magnetic cations or oxygen vacancy to become magnetic but the presence of some structural inhomogeneity proceeds to so called intrinsic diluted magnetic semiconductor [61]. The RTFM arises from the intrinsic defects (oxygen vacancy $\left(\mathrm{V}_{\mathrm{O}}\right)$, zinc vacancies $\left(\mathrm{V}_{\mathrm{zn}}\right), \mathrm{Zn}$ clusters), in $\mathrm{ZnO}$ that promotes interaction 
between localized spins and bound magnetic polarons (BMP) (two polarons separated by small distance is smaller than the diameter of the polaron) [71] which may lead to application in spintronic and high density magnetic storage devices. The observed RTFM behavior in DMS is attributed to the oxygen vacancies. As the substrate temperature increases, the unconventional shape in magnetic loop is observed in Fig.12 (c \& d), i.e, changed from ferromagnetic to diamagnetic state [72].

\section{Conclusion}

The wurtzite $\mathrm{ZnO}$ thin film deposited on glass substrate using perfume atomizer. The structural and micro structural, morphological, optical and photoluminescence property of $\mathrm{ZnO}$ thin film were studied. The XRD patterns reveal preferred orientation along $\left(\begin{array}{lll}1 & 0 & 1\end{array}\right)$ plane upto $400^{\circ} \mathrm{C}$ and above $400^{\circ} \mathrm{C}$ reorientation of planes are observed. Well defined grains with boundaries and wrinkle shaped nanofibers are examined from FESEM as well as roughness of $\mathrm{ZnO}$ thin film revealed from AFM. The low and high surface roughness is observed for the film at $300^{\circ} \mathrm{C}$ and $450^{\circ} \mathrm{C}$ respectively. The $\mathrm{ZnO}$ film at $450^{\circ} \mathrm{C}$ could be used as gas sensors owing to its roughness. The $\mathrm{ZnO}$ thin film exhibits transmittance of $>80 \%$ which is preferred for optoelectronic and solar cell devices. The optical bandgap energy ranges from 3.24 to $3.19 \mathrm{eV}$. The green emission peak of $\mathrm{ZnO}$ thin film is adaptable for LED applications. Different phonon modes are obtained from Raman analysis. The intrinsic exchange interaction arising from defects such as oxygen vacancies, zinc vacancy assists BMP and is responsible for room temperature ferromagnetism in $\mathrm{ZnO}$ thin film.

Conflict of Interest: On behalf of all authors, the corresponding author states that there is no conflict of interest.

Funding: Not applicable 
References

1. C. Jinkai, X. He, W. Wang, W. Xuan, J. Zhou, X. Wang, S R. Dong, S. Garner, P. Cimo, J K. Luo, Mater Chem C. 2, 9109-9114 (2014).

2. J.Wojnarowicz, R. Mukhovskyi, E. Pietrzykowska, S. Kusnieruk, J. Mizeracki, W. Lojkowski, Beilstein J Nanotechnol 7, 721-732 (2016).

3. RM. Mohite, RR. Kothawale, Indian J Chem. 54A, 872-876 (2015)

4. H. Li, X. Li, W. Dong, J .Xi, X Wu, Appl Phys A. 124, 412 (2018).

5. J. Lv, Z. Yang, C. Wang, S. Wang, Y. Ma, G. Zhou, J. Jiang, Q. Zhu, M. Zhao, X. Chen Appl Phys A. 126, 290 (2020).

6. A. R. Nimbalkar, M. G Patil, Physica B. 527, 7-15 (2017).

7. K. Verma, B. Chaudhary, V. Kumar, V. Sharma, M. Kumar, Vacuum. 146, 524-529 (2017).

8. B. Kadem, HA. Banimuslem, A. Hassan, Karbala International Journal of Modern Science. 3, 103-110 (2017).

9. T. Srinivasulu, K. Saritha, K.R. Reddy, Mod Electron Mater. 3,76-85 (2017).

10. T. Long, S. Yin, K. Takabatake, P. Zhnag, T. Sato, Nanoscale Res Lett. 4, 247-253 (2009).

11. L. Znaidi, G S. Illia, S. Benyahia, C. Sanchez, A V. Kanaev, Thin Solid Films. 428, 257-262 (2003).

12. A A. Ahmad, A M. Alsaad, Q M. Al-Bataineh, M A. Al-Naafa, Appl Phys A. 124, 458 (2018).

13. A M. Alsaad, A A.Ahmad, I A. Qattan, Q M. Al-Bataineh, Z. Albataineh, Crystals. 10, 252 (2020).

14. A. López-Suárez, D. Acosta, C. Magaña, F. Hernández, J Mater Sci - Mater Electron. 31, 7389-7397 (2020). 
15. K. Ravichandran, A J. Santhosam, M. Sridharan, Surf Interfaces. 18, 1004122 (2020).

16. G. Ojeda-Barrero, A I. Oliva-Avilés, A I. R D. Oliva, Maldonado, M. Acosta, G M. AlonzoMedina, Mater Sci Semicond Process. 79, 76 (2018).

17. S A. Kamaruddin, K Y. Chan, H K.Yow, M Z. Sahdan, H. Saim, D. Knipp, Appl Phys A. 104, 263-268 (2011).

18. U. Manzoor, M. Islam, L. Tabassam, SU. Rahman, Physica E. 41, 1669-1672 (2009).

19. S. Hamrouni, MS.AlKhalifah, MS. El-Bana, SK. Zobaidi, S. Belgacem, Appl Phys A. 124,555 (2018).

20. V. Ghafouri, A. Ebrahimzad, M. Shariati, Scientia Iranica. 20(3), 1039-1048 (2013).

21. MT. Hosseinnejad, M. Shirazi, M. Ghoranneviss, MR. Hantehzadeh, E. Darabi, Journal of Inorganic and Organometallic Polymers and Materials.26(2),405-12 (2016).

22. H. Sutanto, S. Durri, S. Wibowo, H. Hadiyanto, E. Hidayanto, Physics Research International. 2016, (2016).

23. E. Muchuweni, TS. Sathiaraj, H. Nyakotyo, Heliyon. 3(4), e00285 (2017).

24. M. M. H.Farooqi, R. K. Srivastava, Proceedings of the National Academy of Sciences, India Section A: Physical Sciences. 1-15 (2019).

25. KM. Kang, Y. Wang, M. Kim, HH. Park, Thin Solid Films. 660, 913-919 (2018).

26. CY. Tsay, KC. Pai, Thin Solid Films. 654, 11-15 (2018).

27. N. Kumari, SR. Patel, JV. Gohel, Opt Quant Electron. 50, 1-22 (2018).

28. K. Sadananda, KV. Bangera, GK. Shivakumar, Appl Nanosci. 4,209-216 (2014).

29. AH. Hammad, MS. Abdel-Wahab, S. Vattamkandathil, AR. Ansari, Phys B. 540, 1-8 (2018).

30. O. Dimitrov, D. Nesheva, V. Blaskov, I. Stambolova, S. Vassilev, Z. Levi, V. Tonchev, Mater Chem Phys. 148, 712 - 719 (2014). 
31. M. Shahjahan, MK. Khan, MF. Hossain, S.Biswas, T.Takahashi, J. Vac Sci Technol A. 27(4), 885-888 (2009).

32. L. Znaidi, T. Touam, D. Vrel, N. Souded, S. Ben Yahia, O. Brinza, A. Fischer, A. Boudrioua, Acta Phys Pol A. 121, 165-168 (2012).

33. A. Sharmin, S. Tabassum, MS. Bashar, ZH. Mahmood, Journal of Theoretical and Applied Physics. 13,123-132 (2019).

34. MH. Kabir, MM. Ali, MA. Kaiyum, MS. Rahman, Journal of Physics Communications. 3(10), 105007 (2019).

35. MR. Prasad, M. Haris, M. Sridharan, J Mater Sci: Mater Electron. 28, 11367-11373 (2017).

36. H. Bahadur, AK. Srivastava, RK. Sharma, S. Chandra, Nanoscale Res Lett. 2, 469-475 (2007).

37. NF. Ahmad, K. Yasui, AM. Hashim, Nanoscale Res Lett. 10, 1-9 (2015).

38. MR. Prasad, M. Haris, M. Sridharan, Sens Actuators A. 269, 435-443 (2018).

39. U. Chaitra, MG. Mahesha, D. Kekuda, KM. Rao, Appl Phys A. 125, 394 (2019).

40. S. Talam, SR. Karumuri, N. Gunnam, Synthesis, ISRN Nanotechnology. 2012, (2012).

41. H. Zaka, B. Parditka, Z. Erdélyi, HE. Atyia, P. Sharma, SS. Fouad, Optik. 203,163933 (2020).

42. I. Soumahoro, G. Schmerber, A. Douayar, Colis S, M. Abd-Lefdil, N. Hassanain, A. Berrada, D. Muller, A. Slaoui, H. Rinnert, A. Dinia, J Appl Phys. 109, 033708 (2011).

43. L. Brus, J Phys Chem B. 90, 2555 (1986).

44. NS. Pesika, KJ. Stebe, PC. Searson, J Phys Chem B. 107, 10412 (2003).

45. D. Komaraiah, E. Radha, Y. Vijayakumar, J. Sivakumar, MR. Reddy, R. Sayanna, Modern Research in Catalysis. 5(4),130-146 (2016). 
46. KM. Sandeep, S. Bhat, SM. Dharmaprakash, J Phys Chem Solids 104, 36-44 (2017).

47. N. Srinatha, P. Raghu, HM. Mahesh, B. Angadi, J Alloys Compd. 722, 888-895 (2017).

48. A. Bedia, FZ. Bedia, M. Aillerie, N. Maloufi, B. Benyoucef, Energy Procedia. 50,603-609 (2014).

49. AK. Ghosh, KK. Som, S. Chatterjee, BK. Chaudhuri, Phys Rev B. 51, 4842-4848 (1995).

50. SS. Hussain, H. Noor, S. Riaz, A. Hashmi, S. Naseem, In ACEM16) The 2016 World Congress on Advances in Civil, Environmental, and Materials Research, Korea on August (Vol. 28) (2016).

51. Y. Li, HQ. Wang, H. Zhou, D. Du, W. Geng, D. Lin, X. Chen, H. Zhan, Y. Zhou, J. Kang, Nanoscale Res Lett. 12, 551(2017).

52. PA. Rodnyi, IV. Khodyuk, Optics and Spectroscopy. 111(5), 776-785 (2011).

53. J. Kazmi, PC. Ooi, B.T. Goh, MK. Lee, MM. Wee, SS. Karim, SR. Raza, MA. Mohamed, RSC Adv. 10, 23297-23311(2020).

54. AK. Rana, Y. Kumar, P. Rajput, SN. Jha, D. Bhattacharyya, PM. Shirage, ACS Applied Materials \& Interfaces. 9, 7691-7700, (2017).

55. H. Liu, X. Wang, M. Li, S. Yu, R. Zheng, Ceram Int. 45, 14347-14353 (2019).

56. AS. Gadallah, MM. El-Nahass, Advances in Condensed Matter Physics. 2013 (2013).

57. M. Xin, LZ. Hu, DP. Liu, NS. Yu, Superlattices and Microstructures. 74, 234-241 (2014).

58. V. Russo, M. Ghidelli, P. Gondoni, CS. Casari, A. Li Bassi, J Appl Phys. 115, 073508 (2014).

59. G. Srinivasan, N. Gopalakrishnan, YS. Yu, R. Kesavamoorthy, J. Kumar, Superlattices and Microstructures. 43(2),112-119 (2008). 
60. E. Nowak, M. Szybowicz, A. Stachowiak, W. Koczorowski, D. Schulz, K. Paprocki, K. Fabisiak, S. Los, Applied Physics A. 126(7),1-12 (2020).

61. M. Schumm, ZnO- based semiconductors studied by Raman spectroscopy: semimagnetic alloying, doping and nanostructures. Phd thesis (2008).

62. DC. Agarwal, UB. Singh, S. Gupta, R. Singhal, PK. Kulriya, F. Singh, A. Tripathi, J. Singh, US. Joshi, DK. Avasthi, Scientific reports. 9, 1-12 (2019).

63. ZN. Kayani, A. Usman, H. Nazli, R. Sagheer, S. Riaz, S. Naseem, Applied Physics A. 126, 559 (2020).

64. S. Kumar, A. Sharma, M. Singh, SP. Sharma, Archives of Physics Research. 5, 18-24 (2014).

65. K. Praveena, K. Sadhana, HS. Virk, Solid State Phenomena Series, Trans Tech Publications Ltd. 232, 45-64 (2015).

66. NF. Mott, Philos. Mag. 19, 835-852(1969).

67. Q. Wang, Q. Sun, G. Chen, Y. Kawazoe, P. Jena, Phys. Rev. B 77, 205411(2008).

68. M. Kapilashrami, J. Xu, V. Ström, KV. Rao, L. Belova, Applied Physics Letters. 95, 033104 (2009).

69. S. Kumar, YJ. Kim, BH. Koo, S. Gautam, KH. Chae, R. Kumar, CG. Lee, Materials Letters. 63(2), 194-6 (2009).

70. Z. Yan, Y. Ma, D. Wang, J. Wang, Z. Gao, L. Wang, P. Yu, T. Song, Applied physics letters. 92(8),081911. (2008).

71. N. Ali, AR. Vijaya, ZA. Khan, K. Tarafder, A. Kumar, MK. Wadhwa, B. Singh, S. Ghosh Scientific reports. 9, 1-3 (2019). 
72. D. Aryanto, C. Kurniawan, A. Subhan, T. Sudiro, P. Sebayang, M. Ginting, SM. Siregar, MN. Nasruddin, IOP Conference Series: Materials Science and Engineering. 202, 012049 (2017). 
Figures

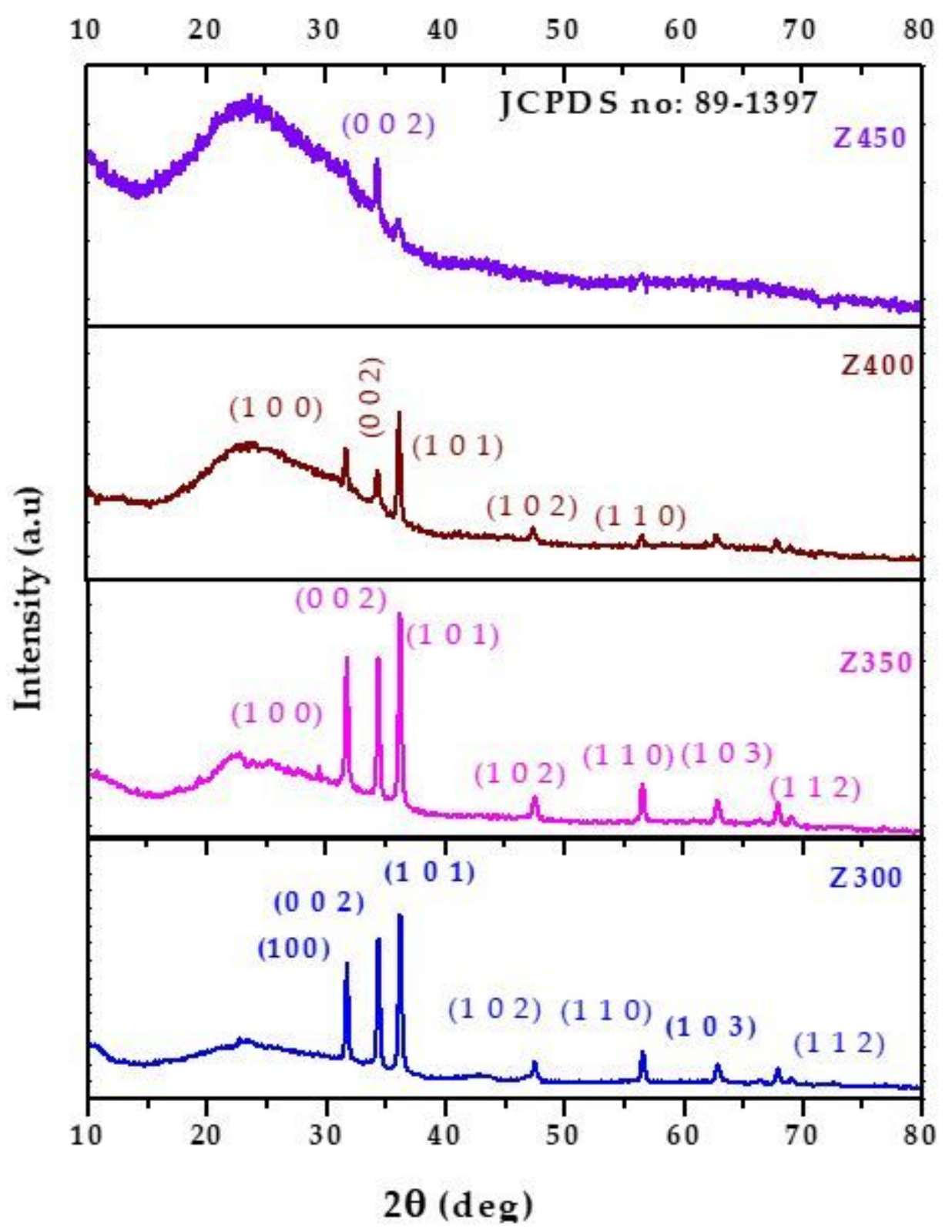

Figure 1

XRD patterns of annealed $\mathrm{ZnO}$ thin film at different substrate temperature 

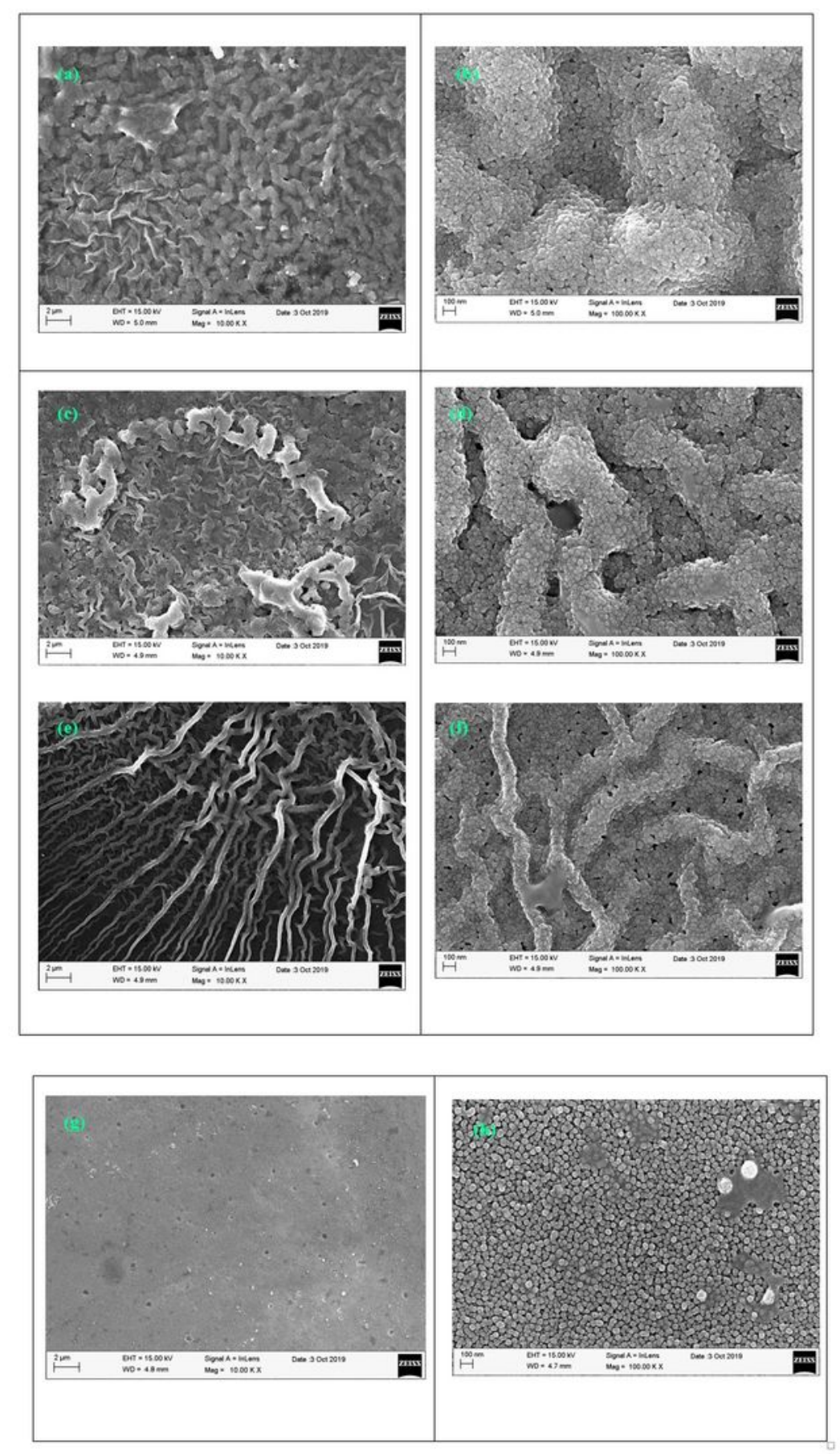

Figure 2

FE-SEM images of ZnO thin films at substrate temperature $(a, b) 300^{\circ} \mathrm{C},(\mathrm{c}, \mathrm{d}) 350^{\circ} \mathrm{C},(\mathrm{e}, \mathrm{f}) 400^{\circ} \mathrm{C}$ and $(\mathrm{g}, \mathrm{h})$ $450^{\circ} \mathrm{C}$ 


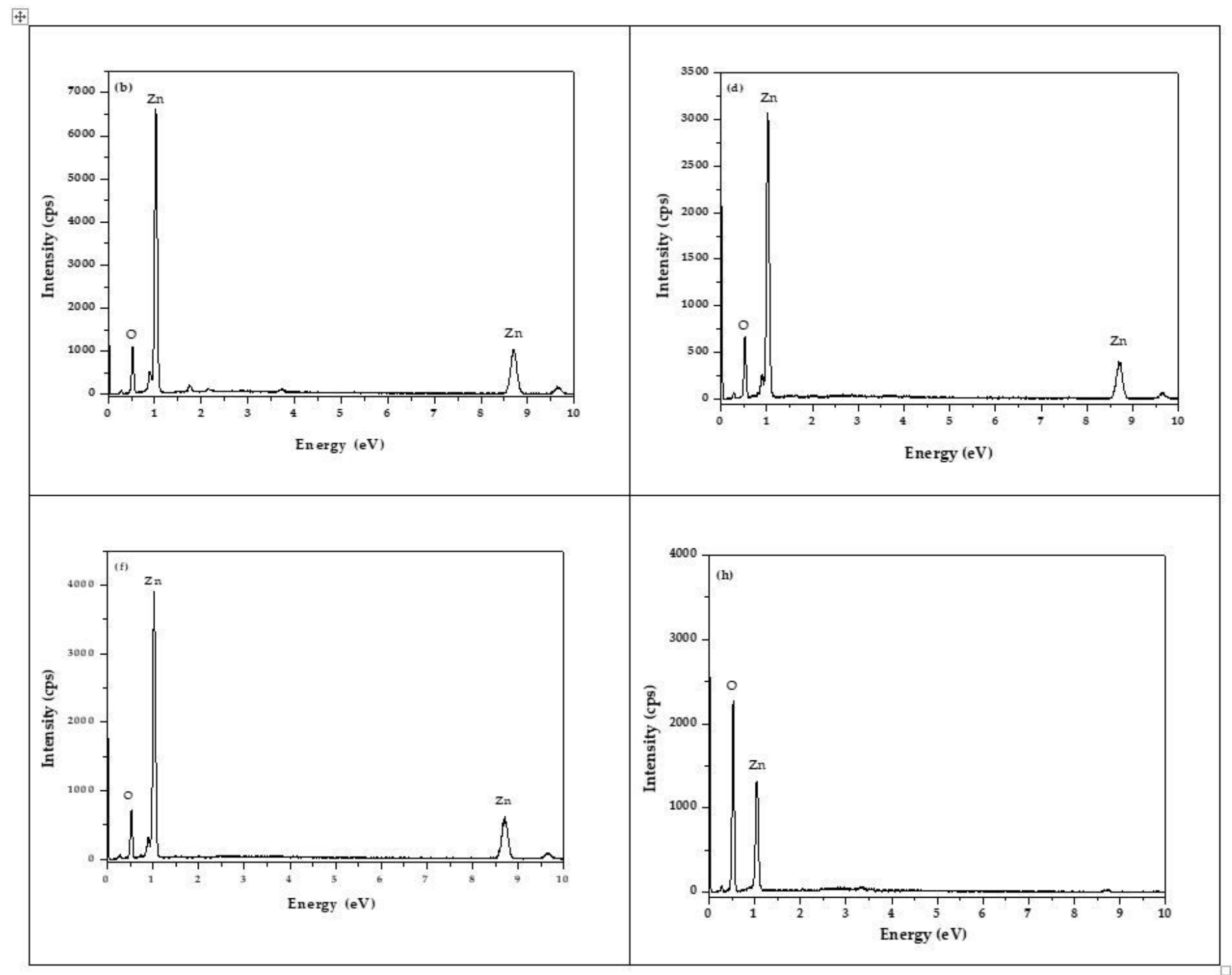

Figure 3

EDS spectra of ZnO film at substrate temperatures 

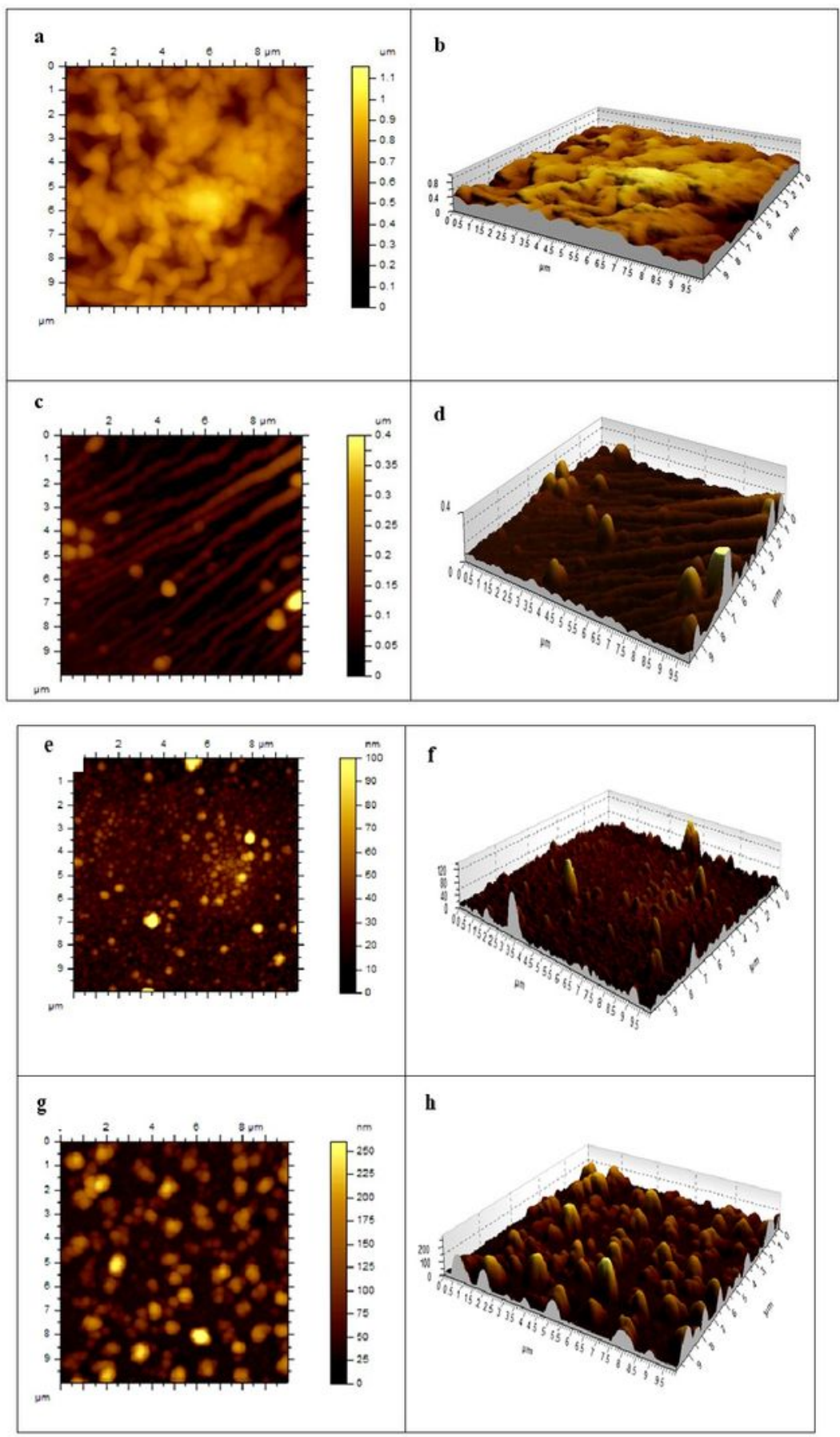

Figure 4

$(a-h), 2 D$ and 3D AFM image of $\mathrm{ZnO}$ thin film at different substrate temperatures. 


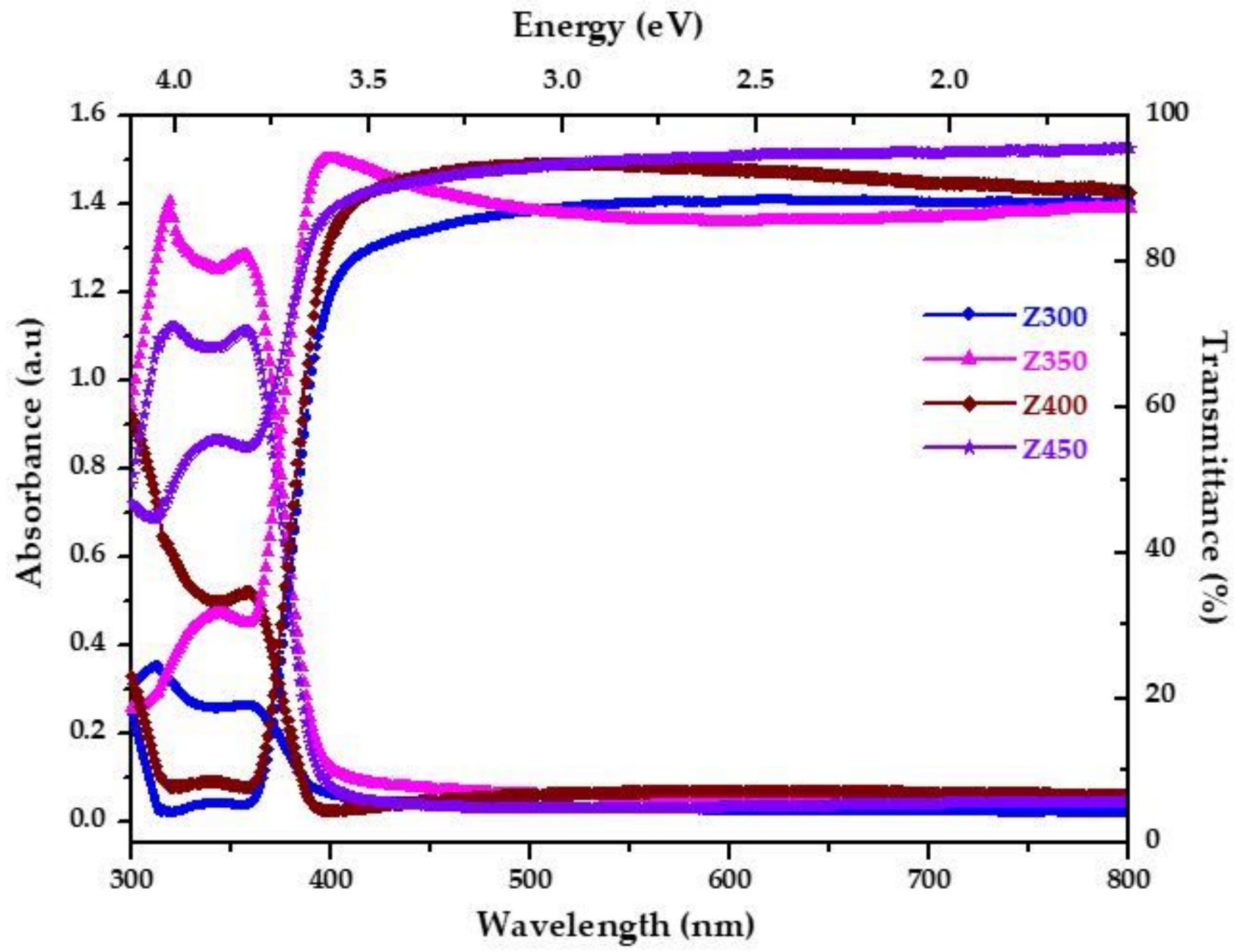

Figure 5

UV Vis absorbance and transmittance spectra of $\mathrm{ZnO}$ thin film 


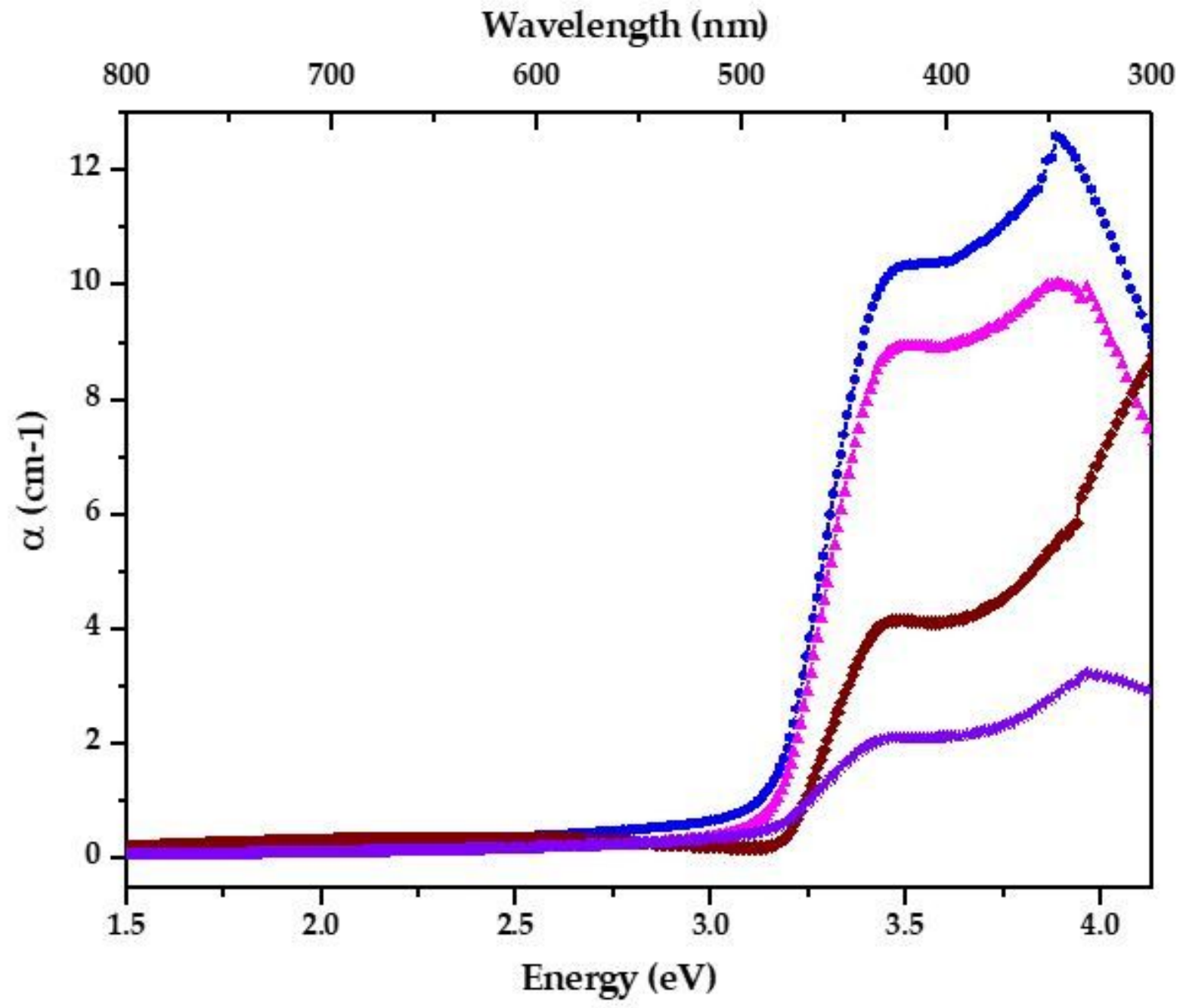

Figure 6

Absorption coefficient Vs Wavelength plot of $\mathrm{ZnO}$ film 

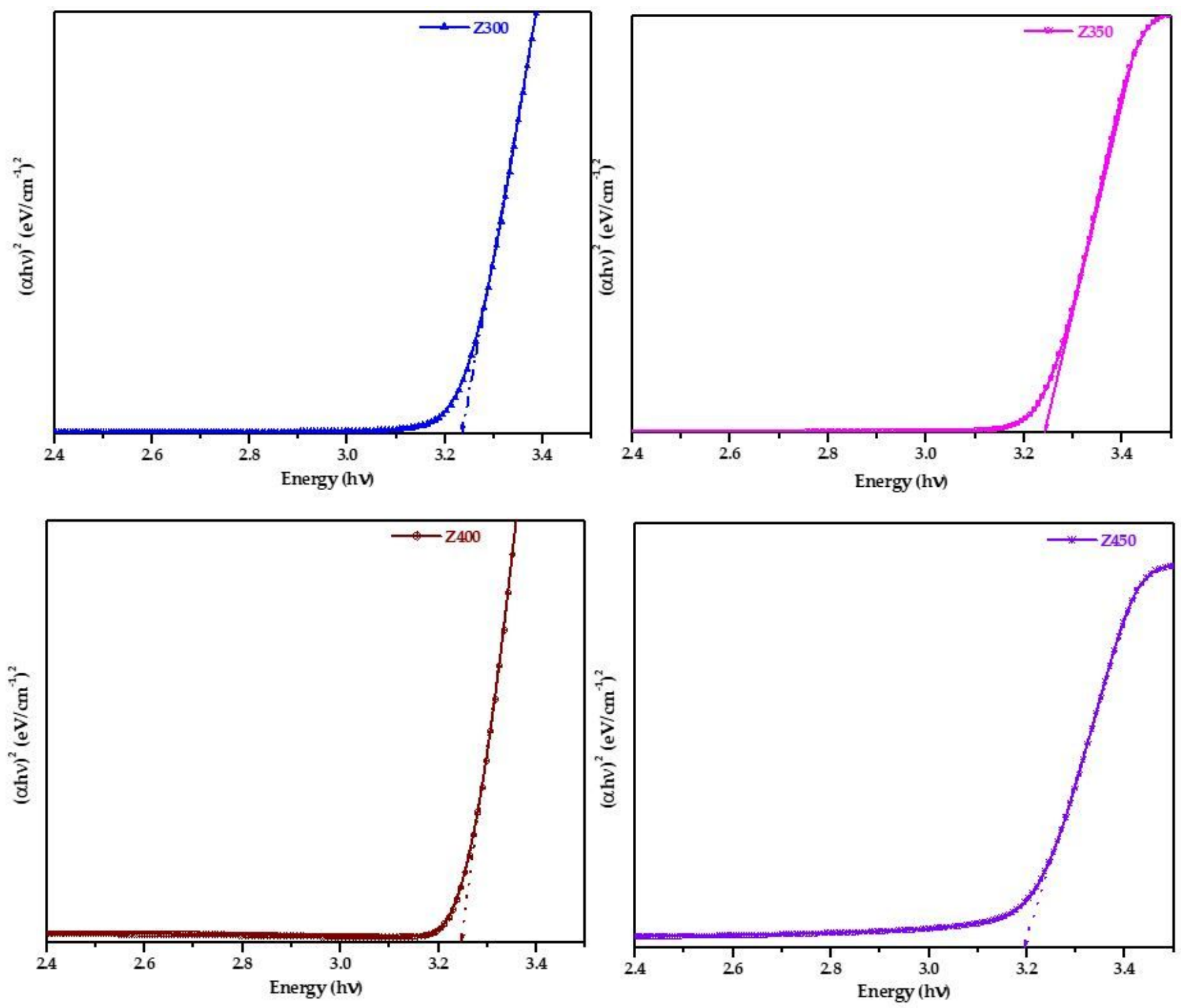

Figure 7

Tauc plot of $\mathrm{ZnO}$ film at substrate temperature (a) $300^{\circ} \mathrm{C}$ (b) $350^{\circ} \mathrm{C}$, (c) $400^{\circ} \mathrm{C}$ and (d) $450^{\circ} \mathrm{C}$. 

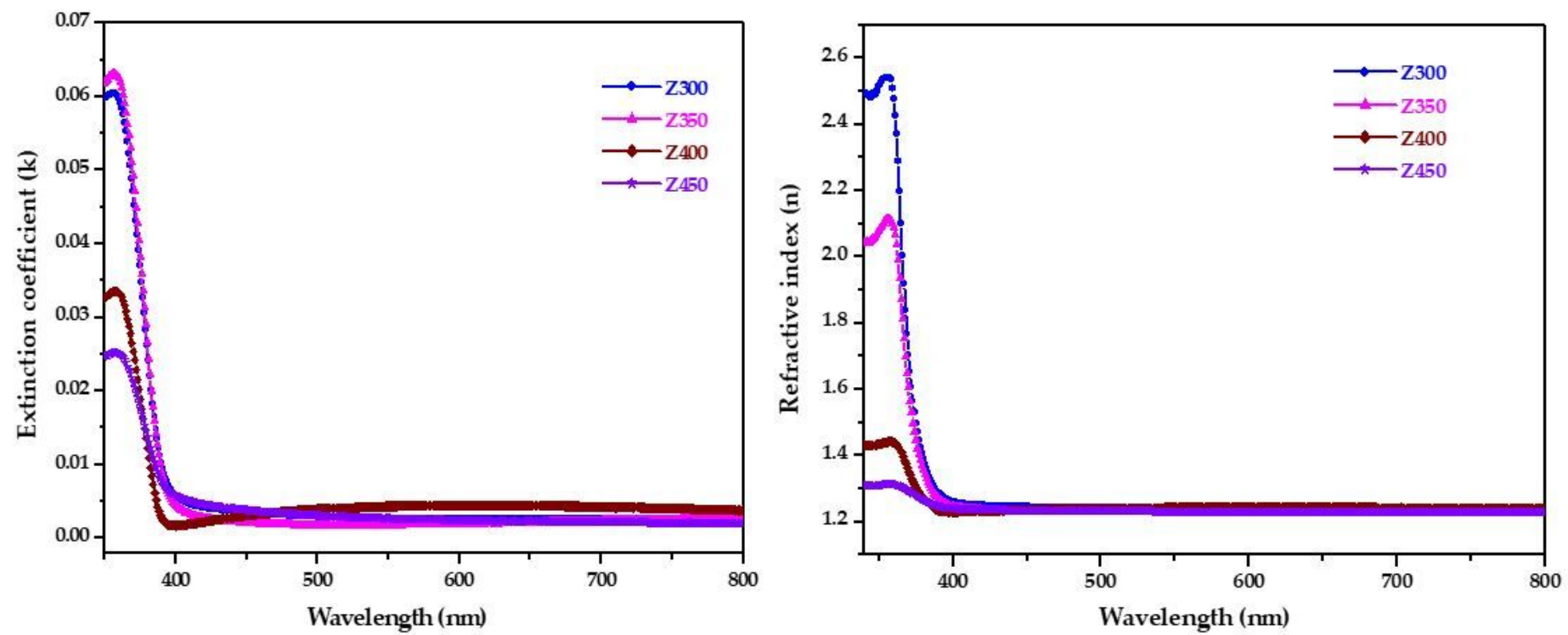

Figure 8

Variation of extinction coefficient and Refractive index with wavelength of $\mathrm{ZnO}$ film 


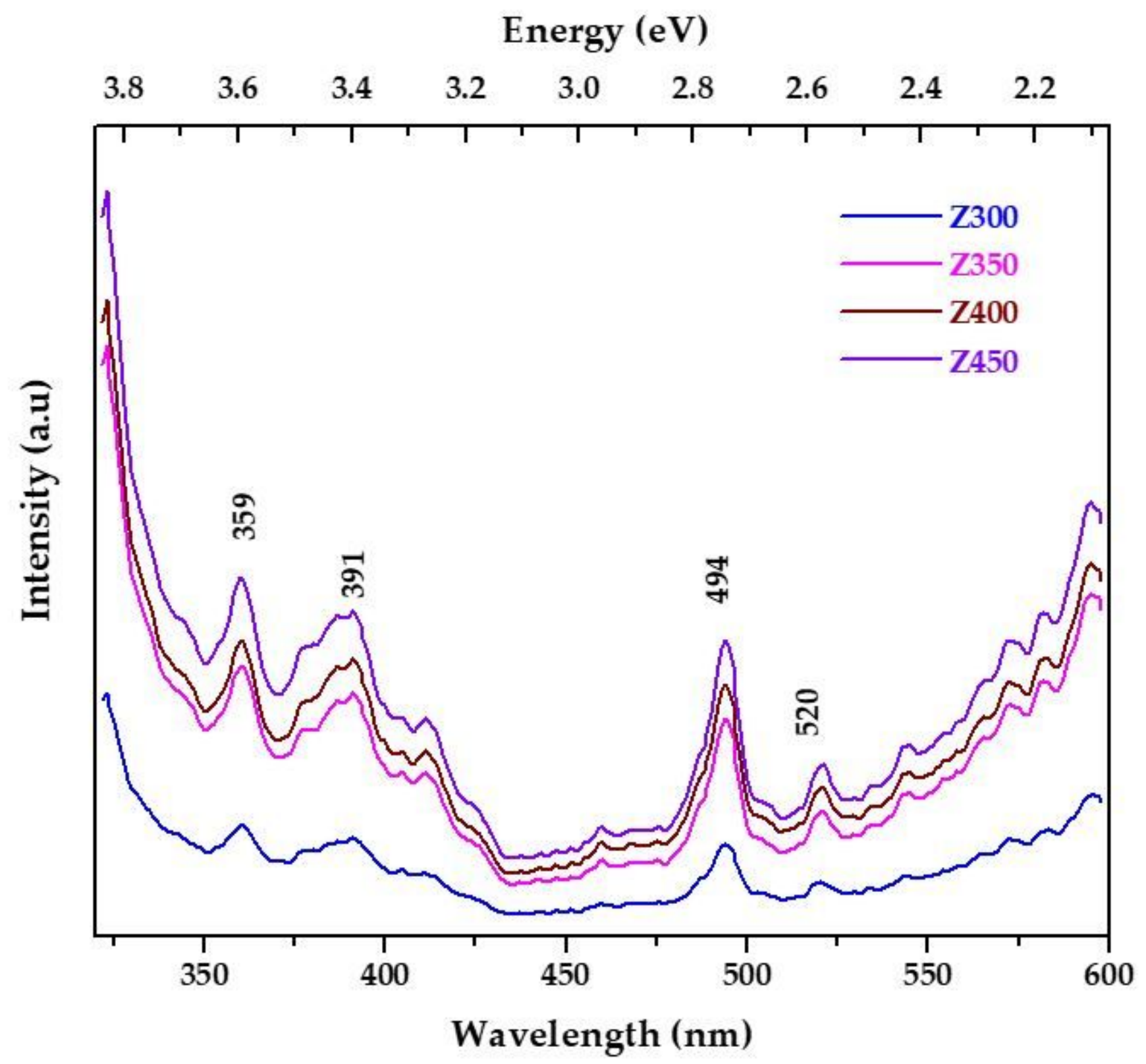

Figure 9

Room temperature PL spectra of $\mathrm{ZnO}$ thin film 


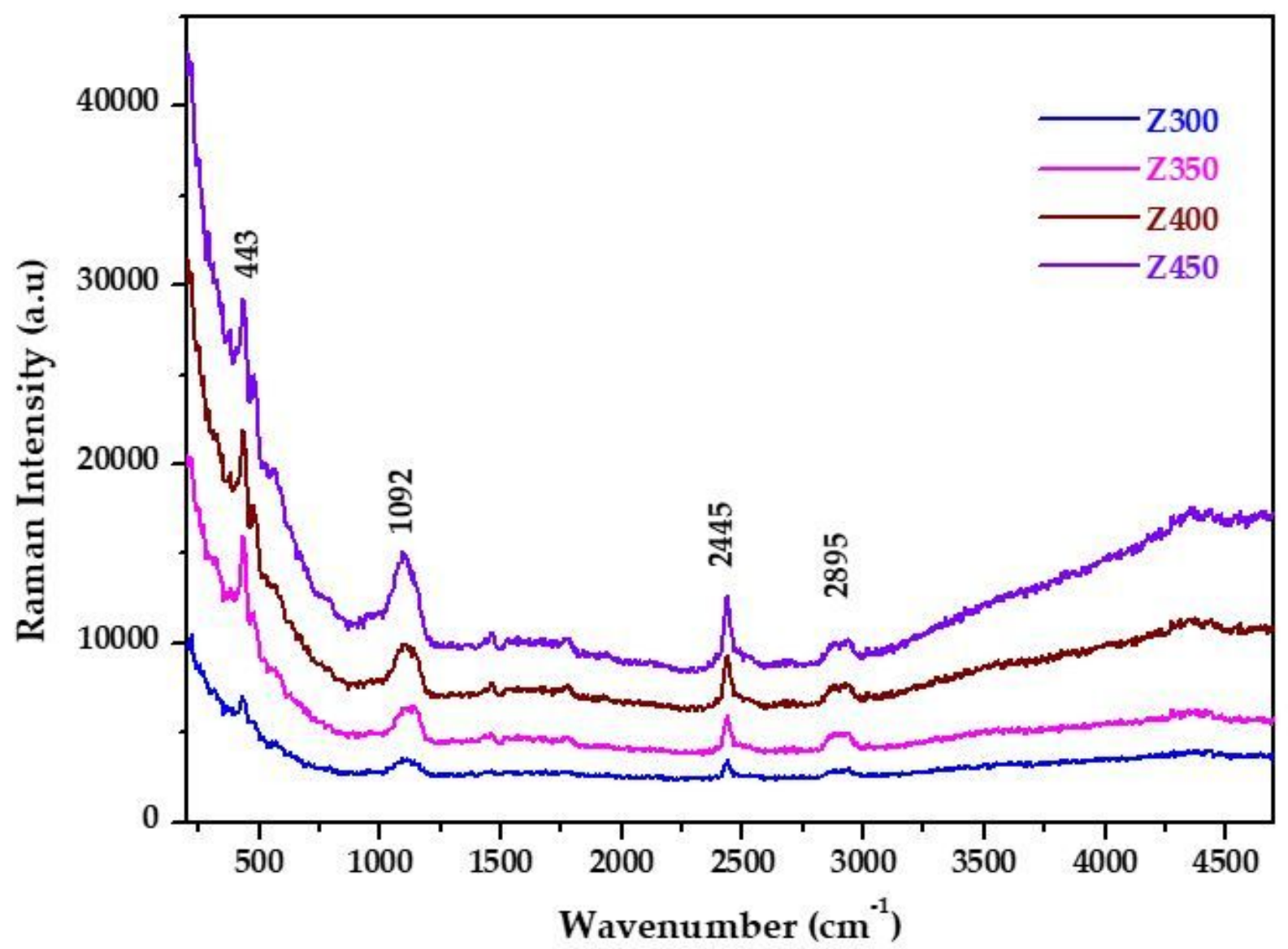

Figure 10

RT Raman Spectra of ZnO thin film 


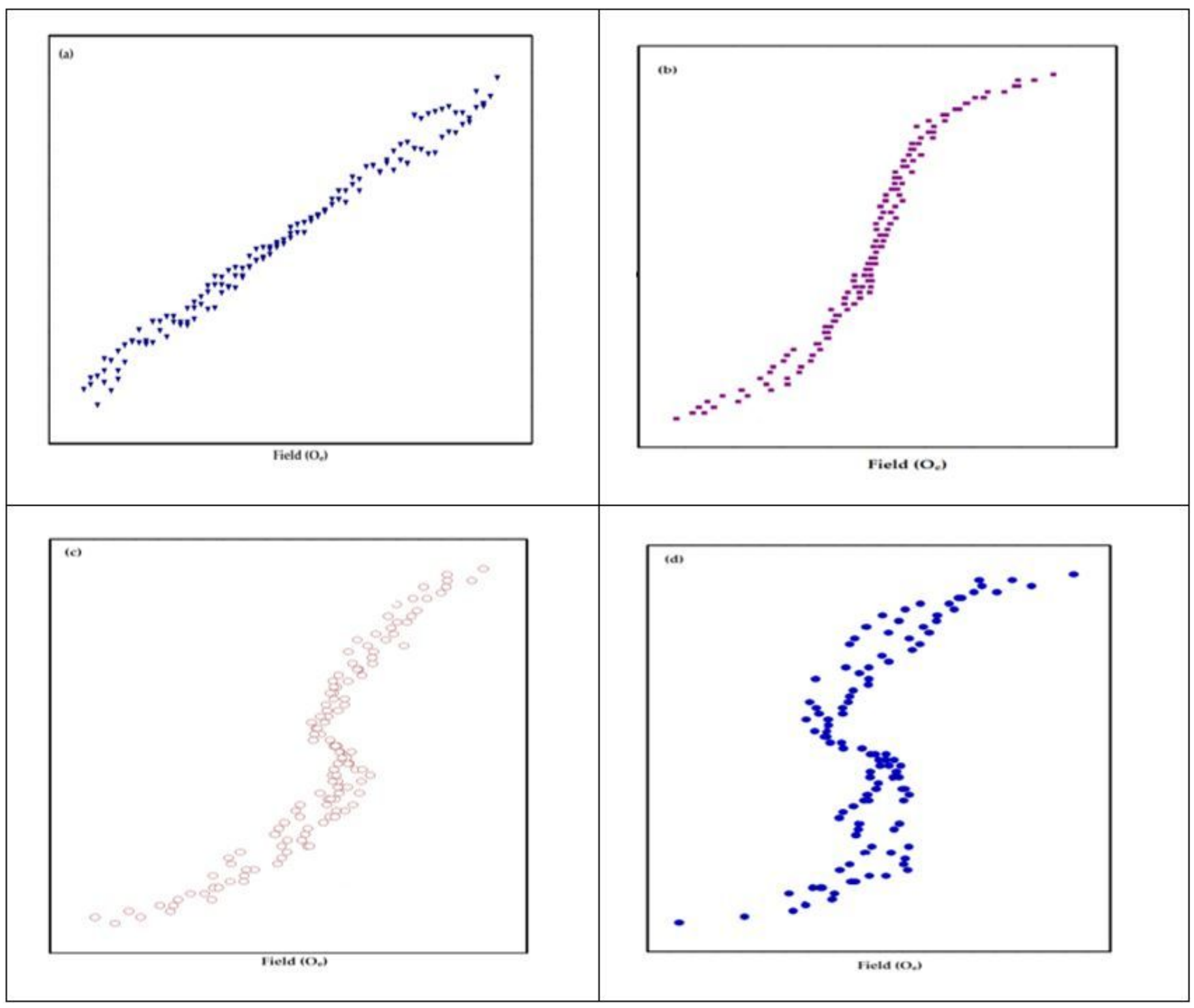

Figure 11

$\mathrm{M}-\mathrm{H}$ plot for $\mathrm{ZnO}$ thin film at (a) $300^{\circ} \mathrm{C}$, (b) $350^{\circ} \mathrm{C}$, (c) $400^{\circ} \mathrm{C}$ and (d) $450^{\circ} \mathrm{C}$ 